OPEN ACCESS

Edited by:

Hongjie Wang,

Pacific Marine Environmental Laboratory (NOAA), United States

Reviewed by:

Andrea J. Fassbender, Monterey Bay Aquarium Research Institute (MBARI), United States Sophie Chu, University of Washington, United States

${ }^{*}$ Correspondence: Burke Hales burke.hales@oregonstate.edu

Specialty section: This article was submitted to Coastal Ocean Processes, a section of the journal Frontiers in Marine Science

Received: 31 July 2020 Accepted: 11 December 2020 Published: 14 January 2021

Citation:

Fairchild W and Hales B (2021) High-Resolution Carbonate System Dynamics of Netarts Bay, OR From

2014 to 2019

Front. Mar. Sci. 7:590236. doi: 10.3389/fmars.2020.590236

\section{High-Resolution Carbonate System Dynamics of Netarts Bay, OR From 2014 to 2019}

\author{
William Fairchild and Burke Hales* \\ College of Earth, Ocean, and Atmospheric Sciences, Oregon State University, Corvallis, OR, United States
}

Netarts Bay is a shallow, temperate, tidal lagoon located on the northern coast of Oregon and the site of the Whiskey Creek Shellfish Hatchery (WCSH). Data collected with an autonomous continuous flow-through system installed at WCSH capable of high-resolution (1 Hz) partial pressure of aqueous $\mathrm{CO}_{2}\left(\mathrm{pCO}_{2}\right)$ and hourly total dissolved inorganic carbon $\left(\mathrm{TCO}_{2}\right)$ measurements, with combined measurement uncertainties of $<2.0 \%$ and $0.5 \%$, respectively, is analyzed over the 2014-2019 interval. Summer upwelling, wintertime downwelling, and in situ bay biogeochemistry represent significant modes of the observed variability in carbonate system dynamics. Summer upwelling is associated with large amplitude diel $\mathrm{pCO}_{2}$ variability, elevated $\mathrm{TCO}_{2}$ and alkalinity, but weak variability in salinity. Wintertime downwelling is associated with bay freshening by both local and remote sources, a strong tidal signature in salinity, $\mathrm{TCO}_{2}$, and alkalinity, with diel $\mathrm{pCO}_{2}$ variability much less amplified when compared to summer. Further, analysis of alkalinity-salinity relationships suggests multiple water masses inhabiting the bay during 1 year: mixing of end-members associated with direct precipitation, coastal rivers, southward displacement of the Columbia River plume, California Current surface and deep upwelled waters. The importance of in-bay processes such as net community metabolism during intervals of high productivity are apparent. These direct measurements of $\mathrm{pCO}_{2}$ and $\mathrm{TCO}_{2}$ have been useful to local hatchery owners who have monitored intake waters following historic seed-production failures related to high- $\mathrm{CO}_{2}$ conditions exacerbated by ocean acidification.

Keywords: ocean acidification, estuarine biogeochemistry, time-series, coastal oceanography, carbonate chemistry, Netarts Bay, Oregon

\section{INTRODUCTION}

Shallow coastal ecosystems, coral reefs, and temperate estuaries are among the most vulnerable oceanographic regimes currently threatened by exposure to elevated atmospheric $\mathrm{CO}_{2}$ and related anthropogenic forcings (Peirson et al., 2015). Enhanced nutrient loading from anthropogenically modified runoff, habitat loss, introduction of invasive species, altered freshwater flow, dredging, expanding 'dead zones' characterized by prolonged hypoxic episodes, and trace metal contamination represent some of the many stressors facing modern estuarine systems (Kennish, 2002; Diaz and Rosenberg, 2008). Additionally, rising sea levels, ocean acidification, and loss of global marine biomass further complicate these vital ecosystems' health and stability and the goods and services they provide (Rabalais et al., 2009). 
Near-shore monitoring studies of oceanic $\mathrm{CO}_{2}$ in the Pacific Northwest have primarily been limited to shipboard measurements in tandem with buoy observations during upwelling intervals (van Geen et al., 2000; Ianson et al., 2003; Hales et al., 2005; Feely et al., 2008; Nemcek et al., 2008; Evans et al., 2011) while more recent work in the Columbia River, Puget Sound, and Salish Sea have introduced $\mathrm{CO}_{2}$ data at higher spatiotemporal resolution (Evans et al., 2013, 2019; Fassbender et al., 2018). The lack of extensive spatiotemporal sampling represents a hurdle in understanding how the dynamic coastal ocean and estuarine environments are interacting with and responding to the cascading and complex problems associated with ongoing climate change. Biophysical processes within shallow coastal shelves and estuarine bodies occur across variable time and space scales (Waldbusser and Salisbury, 2014), from hours to interannual, and forecasting how these environments will respond to climate change continues to be challenging, requiring more expansive and higher resolution coastal monitoring networks.

Despite poor data coverage, our understanding of ocean acidification's impact on organismal life cycles, specifically for larval and juvenile bivalves, shows these organisms experiencing physiological stress across varying levels of $\mathrm{pCO}_{2}, \mathrm{pH}$, and/or saturation state at levels currently observed during various periods of the year (Waldbusser et al., 2011, 2015a; Barton et al., 2012; White et al., 2013). Ocean acidification-related symptoms include, but are not limited to, compromised shell integrity, increased mortality, and reduced recruitment success. Crassostrea gigas, for example, shows enhanced sensitivity to water conditions during the first $48 \mathrm{~h}$ of calcification (Barton et al., 2012). An under sampling of the coastal ocean in both time and space in assessment of coastal water chemistry may result in these bivalve-poor water conditions to be overlooked entirely.

However, high-resolution carbonate sampling is not missioncritical to understand in real-time how ocean acidification is threatening habitat stability, organismal life cycles, and even fisheries economies. During the summer of 2009, Whiskey Creek Shellfish Hatchery in Netarts Bay, OR, sustained significant and prolonged larval oyster mortality in response to intake water which was corrosive and fatal to their broodstock (Barton et al., 2012). A liquid flow-through $\mathrm{pCO}_{2} / \mathrm{TCO}_{2}$ instrument was installed in 2011 to monitor in-take water conditions in real time (Vance, 2012). Coincident with water chemistry monitoring, hatchery operators moved the growing season to earlier in the year and began conditioning incoming seawater with sodium carbonate to elevate saturation states to optimal shellfish growing levels. In an industry worth \$270 million regionally and one which employs $3000+$ people (Barton et al., 2015), implementation of this strategy to mitigate the severe effects of ocean acidification on bivalve mortality continues to be beneficia for hatchery operators at Whiskey Creek. Recreational shellfishing, on the other hand, will be more directly impacted by changing ocean carbonate chemistry since the intertidal zone and shallow estuarine shellfish habitats are directly exposed to dynamic carbonate conditions.
Netarts Bay is a temperate, well-mixed, tidal lagoon located $90 \mathrm{~km}$ south of the Columbia River mouth on the Oregon Pacific coast (Figure 1). Draining only a $4100 \mathrm{Ha}$ watershed, the bay is marine-dominated, receiving freshwater input only from about a dozen very small streams, primarily during the winter storm seasons (McCallum, 1977). A $6 \mathrm{~km}$-long sandspit stretching north-to-south forms the seaward boundary of the estuary and the primary exchange of water occurs at the $\sim 100$ m wide tidal channel located at the northern end of the spit. The net effect of bay hydrology and tidal dynamics results in rapid flushing and water residence times < 12 h (Glanzman, 1971); a single ebb-flood cycle can replace approximately $2 / 3$ of the bay's water during intervals of spring tides.

For this study, we analyzed 6-year time series of highresolution carbonate chemistry measurements taken from Netarts Bay, OR, with the goal to analyze hydrographic and carbonate trends, establish modern baselines, and examine scales of variability that are not often resolved from discrete sampling methods.

\section{MATERIALS AND METHODS}

Whiskey Creek Shellfish Hatchery (WCSH; $45.403^{\circ} \mathrm{N}$, $123.944^{\circ} \mathrm{W}$ ) is located on the eastern bank of Netarts Bay, approximately $2 \mathrm{~km}$ south of the bay's mouth. During the 2007-2008 growing season, hatcheries up and down the Pacific Northwest coast, including WCSH, experienced intermittent but significant mass larval mortality, which was later directly linked to high- $\mathrm{CO}_{2}$ content in intake waters (Barton et al., 2012, 2015). Beginning in 2011, Vance (2012) installed an automated system that combined $\mathrm{pCO}_{2}$ and $\mathrm{TCO}_{2}$ measurements, following the $\mathrm{TCO}_{2}$ system as described by Bandstra et al. (2006) combined with the $\mathrm{pCO}_{2}$ system described by Hales et al. (2004) modified to use a showerhead-style equilibrator. This precursor system was redesigned prior to 2014 and has been in operation more or less continuously in its current configuration since then.

Briefly, hatchery seawater is branched into an adjacent sidelaboratory, passing through a SeaBird Electronics 45 MicroTSG (SBE45) which continuously measures in situ temperature and conductivity, allowing determination of salinity. The intake pipe remains submerged $0.5 \mathrm{~m}$ above the seafloor at an average depth $2 \mathrm{~m}$. Downstream of the TSG is an enclosed-headspace showerhead equilibrator in which the seawater flows over a porous bubbler tube where the recirculated headspace gas is introduced to the equilibration chamber. High water flow rates and vigorous bubbling ensures complete equilibration of the headspace gas $\mathrm{CO}_{2}$ with the dissolved $\mathrm{CO}_{2}$ in the sample stream. The headspace gas is recirculated in a closed loop, passing through a detector unit $\left(\mathrm{LI}-840 \mathrm{~A}^{1}\right)$, where the $\mathrm{CO}_{2}$ content of the gas is measured via infrared spectrometry.

Once an hour, the instrument performs a $\mathrm{TCO}_{2}$ sequence closely following the method of Bandstra et al. (2006). Water is drawn from the main seawater flow through a custom 40micron tangential-flow filter at a pump-controlled $20 \mathrm{~mL} / \mathrm{min}$

${ }^{1}$ licor.com 


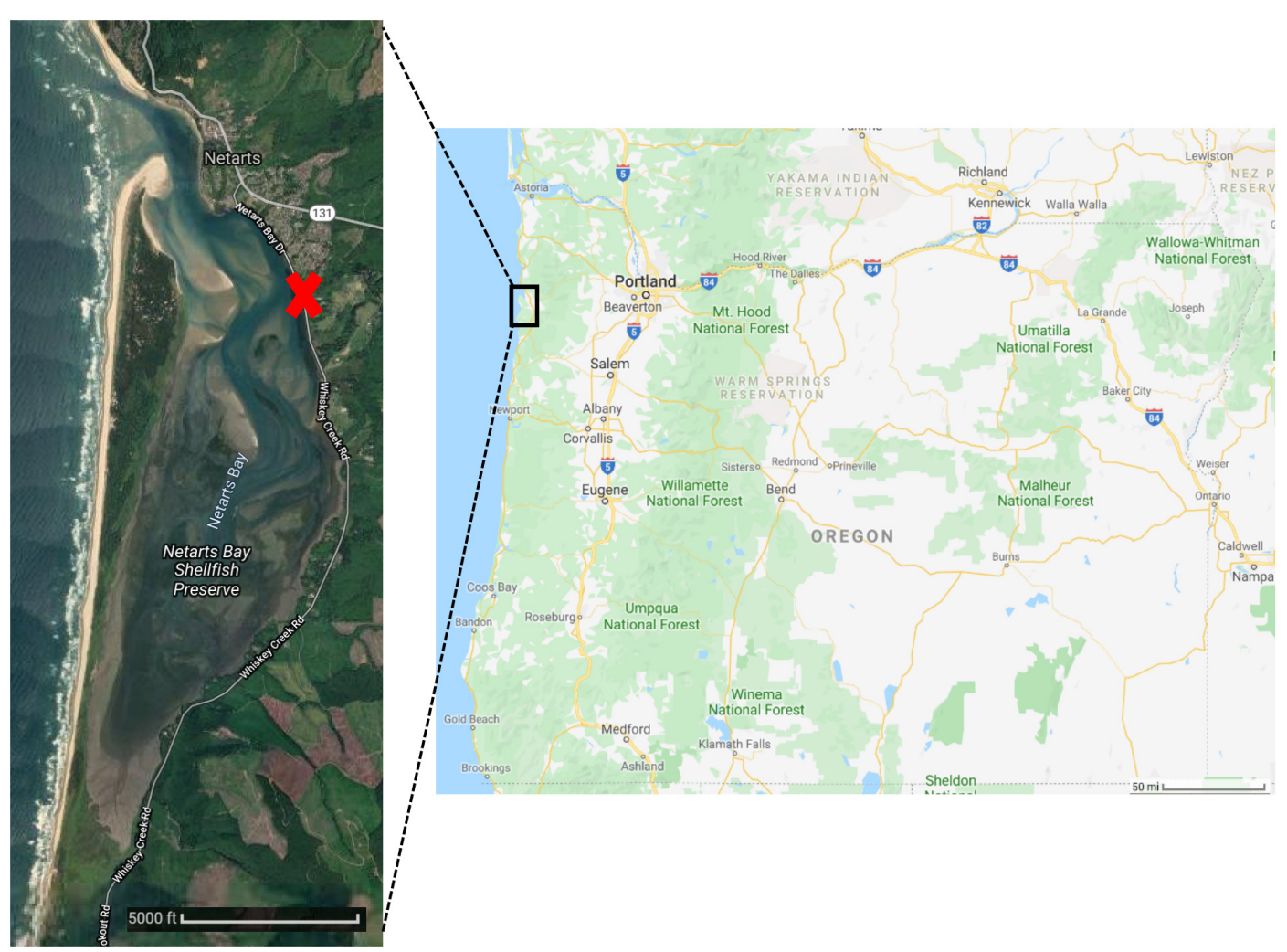

FIGURE 1 | Oregon state map (Right) and satellite imagery of Netarts Bay (Left). Red X marks site of Whiskey Creek Shellfish Hatchery (WCSH). Images courtesy of Google Earth.

and acidified with a $0.1 \mathrm{~mL} / \mathrm{min}$ flow of a solution of $30 \%$ concentrated $\mathrm{HCl}$ in distilled water. The acidified liquid sample stream flows through the lumen-side of a hydrophobic microporous membrane contactor (Liquicell G543), while a $\mathrm{CO}_{2}$ free gas stream controlled at $900 \mathrm{ml} / \mathrm{min}$ by a molecular massflow controller (Alicat Scientific) flows counter to the liquid stream on the shell-side of the contactor. A steady-state mass balance governs the $\mathrm{CO}_{2}$ composition of the outlet gas stream. With precisely controlled gas and liquid flows, the $\mathrm{xCO}_{2}$ of the effluent gas stream, measured by the LI-840A, is proportional to the $\mathrm{TCO}_{2}$ of the sample water.

The instrument is controlled by a computer and a custom acquisition and control program developed in LabView. Data (LI-840A, mass flow, and SBE45 output, and several operational analog sensors) are sampled and stored at $1-\mathrm{Hz}$ frequency. At user-specified intervals (30 s here), the program calculates medians of the continuous data $\left(\mathrm{pCO}_{2}\right.$, salinity, and temperature), applies calibrations and corrections, and performs carbonate-system calculations to give real-time estimates of water alkalinity, $\mathrm{pH}_{t}$ (presented here on the total hydrogen ion scale), and $\mathrm{CaCO}_{3}$ mineral saturation states.

\section{Calibrations and Standards}

Both gas and liquid-phase standards are run automatically at user-specified intervals ( $6 \mathrm{~h}$ for this work) to verify detector accuracy and the relationship between $\mathrm{TCO}_{2}$ outlet strip gas and inlet-water $\mathrm{TCO}_{2}$ concentration. Gas standards are a set of three cylinders of gravimetrically prepared mixtures of $\mathrm{CO}_{2}$ in ultrapure air, typically spanning the range of 200-2000 ppm, but there were variations over the course of this study. The LI$840 \mathrm{~A}$ is factory-linearized over a range of 0-20000 ppm, and we have verified this linearity up to $7000 \mathrm{ppm}$ in the laboratory. In the instances where the natural dynamic range exceeds the calibration range, we are confident that our linear regression $\left(\mathrm{R}^{2}\right.$ typically $>0.999, n \geq 3$ ) can be extended to any $\mathrm{CO}_{2}$ level observed here. Liquid standards are three solutions of $\mathrm{NaHCO}_{3}$ and $\mathrm{Na}_{2} \mathrm{CO}_{3}$ in deionized water, in proportions selected to maintain near-ambient solution $\mathrm{pCO}_{2}$ at $\mathrm{TCO}_{2}$ concentrations of 1200,1800 , and $2400 \mu \mathrm{mol} / \mathrm{kg}$. The liquid calibration is likewise highly linear $\left(\mathrm{R}^{2}\right.$ typically $\left.>0.999, n \geq 3\right)$. Calibration sequences are processed, and regressions performed in real time. At each calibration interval, measurements of outside air $\mathrm{xCO}_{2}$ and barometric pressure are made.

Raw LI-840A xCO $\mathrm{AC}_{2}$ measurements are corrected using linear regressions performed from bracketing gas standard sequences using gases of known $\mathrm{CO}_{2}$ mixing ratio. A drift correction is applied to the converted data using a linear interpolation in time between adjacent standard sequences. Calibrated $\mathrm{xCO}_{2}$ during $\mathrm{pCO}_{2}$ operations are converted to $\mathrm{pCO}_{2}$ using the total headspace pressure, which is undetectably different from ambient atmospheric pressure. Calibrated $\mathrm{xCO}_{2}$ data during $\mathrm{TCO}_{2}$ operations are converted to $\mathrm{TCO}_{2}$ in $\mu \mathrm{M}$ using the 
set of liquid standard sequences which bookend any given $\mathrm{TCO}_{2}$ measurement, and subsequently converted to $\mu \mathrm{mol} / \mathrm{kg}$ using sample density calculated from the SBE45 temperature and salinity. A density and CRM correction are applied postconversion to arrive at units of $\mu \mathrm{mol} / \mathrm{kg}$. Synchronizing hourly $\mathrm{TCO}_{2}$ measurements with temperature, salinity, and timeweighted interpolated $\mathrm{pCO}_{2}$ value allows for calculation of hourly alkalinity (Eq. 1), $\mathrm{pH}_{t}$, and mineral saturation with use of a program such as $\mathrm{CO} 2 \mathrm{Sys}$ or $\mathrm{CO} 2 \mathrm{Calc}$, though we use our own calculation program here (CarbCalc; developed by B. Hales). For the custom CarbCalc function, we use the dissociation constants of water provided by Millero (2010), calcite and aragonite solubility constants from Mucci (1983), and constants for equilibrium of carbonic acid from Millero (2010) and boric acid by Dickson (1990).

$$
\begin{aligned}
& \text { Alkalinity }= \\
& {\left[\mathrm{HCO}_{3}^{-}\right]+2\left[\mathrm{CO}_{3}^{2-}\right]+\left[\mathrm{B}(\mathrm{OH})_{4}^{-}\right]+\left[\mathrm{OH}^{-}\right]-\left[\mathrm{H}^{+}\right]}
\end{aligned}
$$

To cross-check the accuracy of the instrument's $\mathrm{TCO}_{2}$ response, certified reference materials (CRM) provided by Scripps Institute of Oceanography (Dickson laboratory) were run roughly every other month throughout the study. These CRMs contain highly accurate and precisely known concentrations of $\mathrm{TCO}_{2}$ and alkalinity. On-site $\mathrm{TCO}_{2}$ measurements of these CRM's consistently produce correction factors $0.985 \pm 0.005(n=14)$, so we applied a single correction of 0.985 to our $\mathrm{TCO}_{2}$ data over the duration of the study. This implies an uncertainty of $\pm 0.5 \%$ $(\sim 10 \mu \mathrm{mol} / \mathrm{kg})$ in $\mathrm{TCO}_{2}$, which exceeds that achievable in a more controlled operation (Bandstra et al., 2006), but is quite small in the context of this dynamic setting where $\mathrm{TCO}_{2}$ ranges from 1200 to $2300 \mu \mathrm{mol} / \mathrm{kg}$ during the year.

On a weekly basis, discrete check samples were collected in $350 \mathrm{ml}$ amber glass bottles downstream of the equilibration chamber, poisoned with mercuric chloride, and capped with metal bottle caps. These samples were analyzed in the Hales' laboratory at Oregon State University using combined $\mathrm{pCO}_{2} / \mathrm{TCO}_{2}$ measurements as described above but modified for discrete samples. Check samples $(n=237)$ reveal that $\mathrm{pCO}_{2}$ measurements at WCSH are within $\pm 5 \%$ of the discretesampler system, while $\mathrm{TCO}_{2}$ measurements are within $\pm 1 \%$. Discrepancies between the two measurements can arise from human error such as inconsistent sampling procedure, failure to adequately poison the discrete sample bottle, and occasional transcription errors. We believe these disagreements represent extreme bounds on the uncertainty of the system, particularly for $\mathrm{pCO}_{2}$ which is more robust in the continuous equilibration than in discrete bottle samples. For example, the equilibration of a discrete liquid sample containing headspace gas, albeit relatively small in volume, inherently and unpreventably alters the exact chemistry of the sample. The asymptote of an infinitesimal headspace and an infinite water sample is more closely approached by a fixed, recirculated gaseous headspace equilibrated with a continuous flow of seawater than by the discrete liquid sample in a bottle.

Full data processing, including a suite of statistical analyses, was performed using compiled language and programs written in RStudio (version 1.2.5033). Complete annual data coverage proved challenging due to several internal and external circumstances. Such instances included times of seawater flow stoppage, either in the main hatchery supply-specifically during late September when hatchery operations slow down and pipes are cleaned or replaced-or in the branch to the laboratory, clogs in the headspace recirculation airflow, LI$840 \mathrm{~A}$ detector failures, $\mathrm{HCl}$ depletion, etc. These failures were recognizable from anomalous system variables, such as flow or pressure readings, atypical temperature and salinity readings (i.e., negative salinities), among others. QA/QC was applied manually to remove instances of system malfunction. Despite various setbacks, we were able to process and analyze $\sim 75 \%$ of measurements taken from 2014 to 2019.

\section{RESULTS}

The time series data presented below represent a highly dynamic system, with multiple timescales of variability. Our examination of the data revealed four key timescales of variability: diel, which persists throughout the year; seasonal, reflecting the transition between predominantly upwelling summer and predominantly downwelling winter conditions; summer-event variability associated with upwelling/relaxation cycles; and winter-event variability associated with storms and precipitation events. There are other scales of variability present, such as sub-hourly, but our discussion will focus on elucidating those listed above, using the data from 2017 as exemplary in terms of data coverage before presenting the 2014-2019 composite.

\section{Summer and Winter 7-Day Direct Observations}

Plots of the measurements of temperature, salinity, and $\mathrm{pCO}_{2}$ at 30-s resolution, and $\mathrm{TCO}_{2}$ at hourly resolution for two 7-day periods in February and June of 2017 are shown in Figure 2. Modeled tide height, relative to Crescent City, CA (NOAA reference station ID: 9419750) is shown as a spline-fit of daily high-and-low tides (data courtesy of https://tidesandcurrents. noaa.gov/), and shading represents local day- and night-time, yellow and blue, respectively.

Plots of a 7-day interval in February of 2017 (day-of-year 48-55) are shown in Figure 2 (left). Temperature varies weakly between 9.4 and $11.2^{\circ} \mathrm{C}$ without obvious diel or tidal character. Salinity varies strongly between 26 and 31, with a clear tidal covariance. $\mathrm{pCO}_{2}$ ranges between 325 and $420 \mu$ atm with evident diel amplitude, but with a dramatically smaller dynamic range than seen in the summer. The overall trend of decreasing $\mathrm{pCO}_{2}$ throughout the afternoon and build-up throughout nighttime persists in winter. $\mathrm{TCO}_{2}$ ranges from 1620 to $2000 \mu \mathrm{mol} / \mathrm{kg}$, which is large compared to the summer observations. That variability is largely positively correlated to salinity for this period $\left(r^{2}=0.91, n=153\right)$, with diel variability and $\mathrm{pCO}_{2}$ co-variance less evident than seen in summer.

A weekly snapshot of summertime in June of 2017 is detailed in Figure 2 (right). In-bay temperature ranges between 14 and $17.5^{\circ} \mathrm{C}$ with little systematic variability from day-of-year 

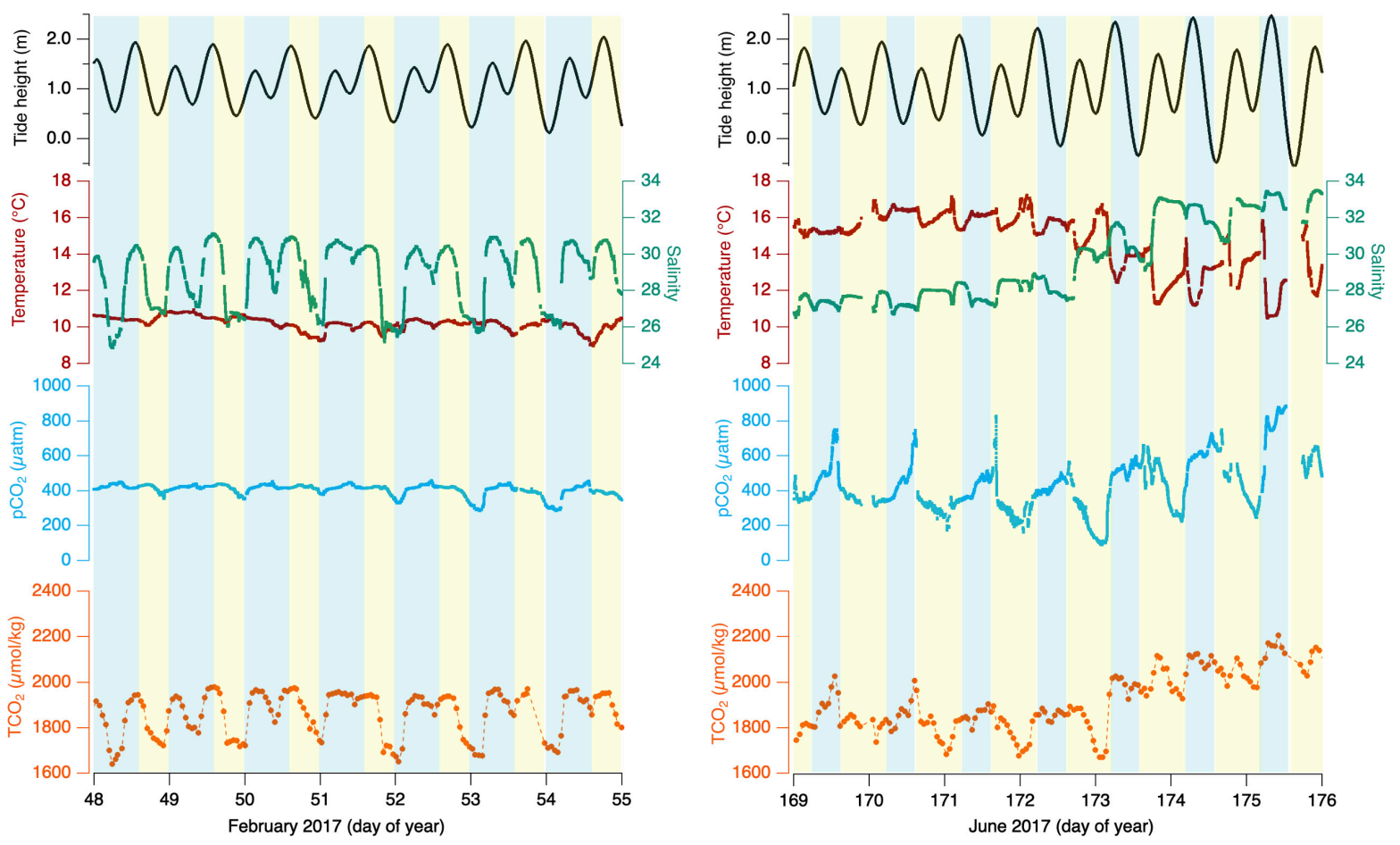

FIGURE 2 | 7-day period winter (Left) and summer (Right) 2017 for Netarts Bay, OR, time in day of year UTC. Temperature (red line), salinity (teal line), pCO 2 (cyan line), $\mathrm{TCO}_{2}$ (orange dots connected by dashed line), and estimated tide height (black line). Blue shading indicates local nighttime and yellow shading indicates local daytime.

169-173 until decreasing in temperature but growing in tidal variability from day 173 to 176 . Salinity experiences variability more closely synchronized with the local tide stage, initially varying between 26.2 and 28 until day 173, when salinity increases to 33.5 and remains high through day $176 . \mathrm{pCO}_{2}$ shows strong diel variability from $<200$ to $>800 \mu$ atm in this interval. $\mathrm{pCO}_{2}$ tends to increase during the night hours, peaking either immediately before or shortly after sunrise, and then rapidly falls throughout the day, reaching daily minima in late afternoon or early evening. Early in the observation period, $\mathrm{TCO}_{2}$ shows clear $\mathrm{pCO}_{2}$-synchronous diel variability with dawn maxima around $1900 \mu \mathrm{mol} / \mathrm{kg}$ and late afternoon minima around $1700 \mu \mathrm{mol} / \mathrm{kg}$, until late in day 173 , when $\mathrm{TCO}_{2}$ shows a large increase $(\sim 150 \mu \mathrm{mol} / \mathrm{kg})$ coinciding with the step up in salinity. Following day $173, \mathrm{TCO}_{2}$ continues to show $\mathrm{pCO}_{2}$ synchronous diel variability with morning maxima slightly over $2100 \mu \mathrm{mol} / \mathrm{kg}$ and evening minima slightly under $2000 \mu \mathrm{mol} / \mathrm{kg}$.

\section{Summer and Winter 7-Day Derived Observations}

As discussed in the methods section, hourly $\mathrm{TCO}_{2}$ measurements are combined with a synchronized, time-interpolated $\mathrm{pCO}_{2}$ value to calculate hourly alkalinity, $\mathrm{pH}_{t}$, saturation state, and a series of other carbonate variables including individual inorganic carbon species as determined through thermodynamic relationships. Figure 3 plots alkalinity, $\mathrm{pH}_{t}$, and the saturation state of aragonite $\left(\Omega_{a}\right)$ for the same two 7-day intervals of Figure 2 .
Figure 3 (left) shows the corresponding wintertime-interval alkalinity, $\mathrm{pH}_{t}$, and $\Omega_{a}$. Alkalinity varies by a large range compared to the summer interval, from 1700 to $2100 \mu \mathrm{eq} / \mathrm{kg}$; however, the variability is more strongly coupled to salinity variability than to any diel pattern. $\Omega_{a}$ varies between $\sim 1$ and 1.5 , with an apparent mixture of covariance between salinity and $\mathrm{pCO}_{2} \cdot \mathrm{pH}_{t}$ varies between $\sim 7.9$ and 8.1 , and, while lateday maxima correspond to late-day $\mathrm{pCO}_{2}$ minima, there are additional variations that hint at a relation to salinity.

For the summer interval (right), alkalinity is largely covariant with the $\mathrm{TCO}_{2}$ data in the first 4 days of the interval, varying from 1900 to $2100 \mu \mathrm{mol} / \mathrm{kg}$. In the final 3 days, alkalinity increases with the step up in salinity, and then experiences minimal variability between 2100 and $2150 \mu \mathrm{mol} / \mathrm{kg}$ for the remainder of the record. The saturation state ranges from 1.0 to over 4.6 in similar diel cycling as the $\mathrm{pH}_{t}$ values, and thus anti-correlated with in situ $\mathrm{pCO}_{2}$, with lowest saturation states in late-evening or early morning, and highest values in late afternoon. $\mathrm{pH}_{t}$ behavior is primarily anti-correlated with the $\mathrm{pCO}_{2}$ observations $\left(r^{2}=-0.93, n=31\right)$, showing the diel pattern of lowest values $\sim 7.8$ in the early morning, and highest values, $\sim 8.1$ or higher, in late afternoon or early evening.

\section{Single Year Direct Observations}

Annual patterns for the direct measurements taken during the representative year 2017 are shown in Figures 4A-F. The leading inferred drivers at the seasonal timescale are the 

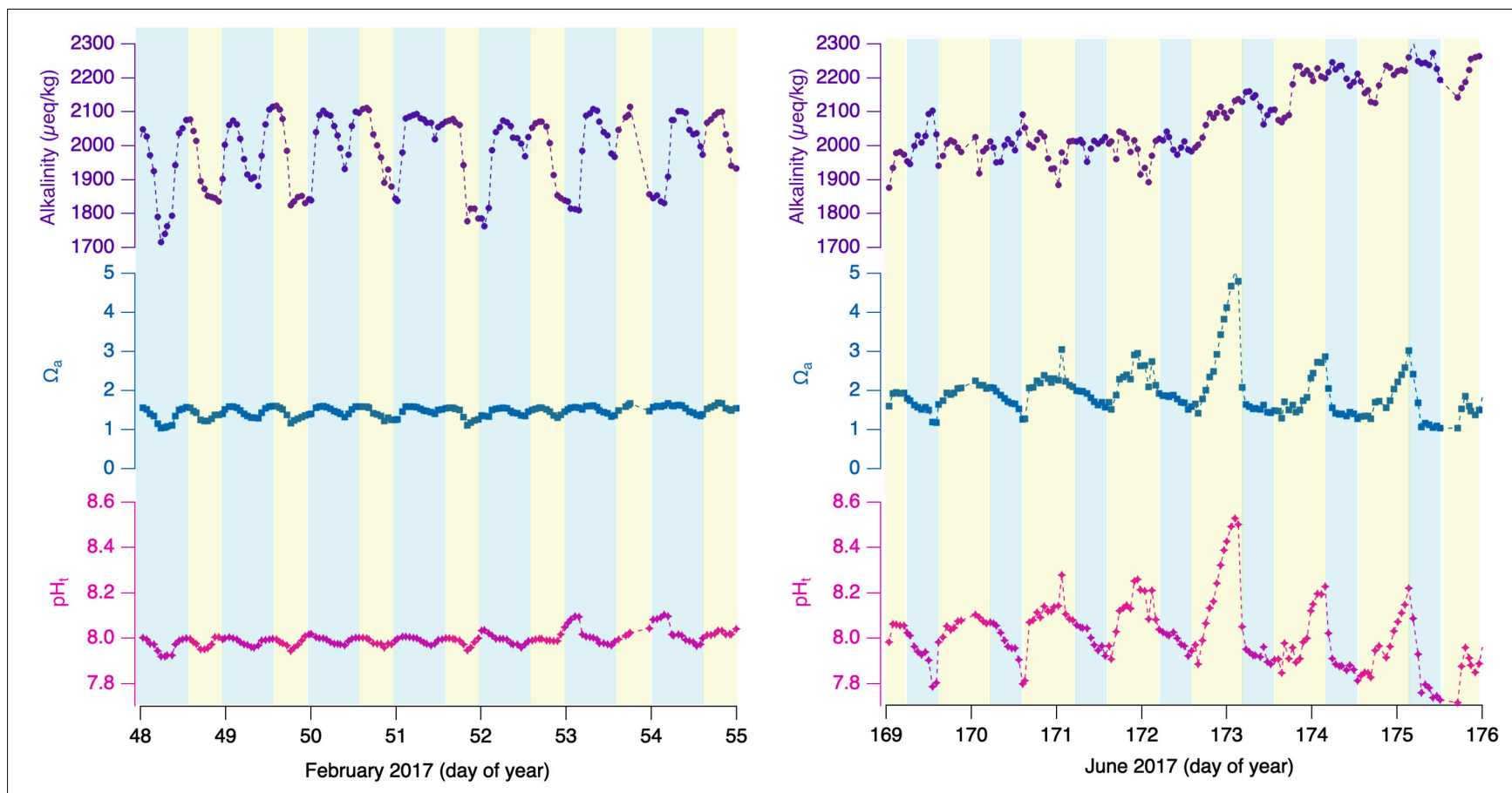

FIGURE 3 | 7-day period winter (Left) and summer (Right) 2017 for Netarts Bay, OR. Calculated alkalinity (purple dots connected by dashed line), saturation state of aragonite ( $\Omega_{a}$, blue squares connected by dashed line), and $\mathrm{pH}$ (pink stars diamonds connected by dashed line). Blue shading indicates local nighttime and yellow shading indicates daytime.

upwelling/downwelling forcing and the related precipitation. In winter, winds are predominantly poleward and lead to onshore convergence and downwelling. Frequently accompanying poleward wind forcing are storm events that bring instances of high precipitation to the bay. In summer, the winds reverse to become primarily equatorward, causing coastal divergence and upwelling. Little precipitation occurs throughout these summer months. Not shown for the location is the annual photoperiod variation from $\sim 8.5$ to $15.5 \mathrm{~h}$ between winter and summer solstices. Separating the winter and summer seasons are spring and fall transition periods, where the character of the dominant season fades and that of the forthcoming season grows.

The influence of these seasonal forcings are evident in the temperature and salinity time series. While the coldest temperatures are seen in winter, summertime minimum temperatures are nearly as low $\left(\sim 8^{\circ} \mathrm{C}\right)$, corresponding to the highest bay salinities and reflecting the influence of deep upwelling-source water. However, winter-time temperatures show relatively little variability $\left(8-12^{\circ} \mathrm{C}\right)$, with maxima rarely $>12^{\circ} \mathrm{C}$, while summer maximum temperatures are routinely $>15^{\circ} \mathrm{C}$. Salinity shows nearly opposite character. The highest values approach 34 in summer, when there is relatively little variability. In contrast, winter salinity is rarely above 32, and minimum values corresponding to high-precipitation events fall as low as 16. The seasonality is perhaps most evident in the dramatic change in the $\mathrm{pCO}_{2}$ variability. In winter, $\mathrm{pCO}_{2}$ values rarely exceed $500 \mu \mathrm{atm}$, and rarely fall below $300 \mu \mathrm{atm}$. In contrast, summer $\mathrm{pCO}_{2}$ ranges between minima $\sim 190 \mu \mathrm{atm}$ and maxima $\sim 1600 \mu \mathrm{atm}$.
$\mathrm{TCO}_{2}$ variability show distinctly different behavior from $\mathrm{pCO}_{2}$ when examined in the composite year as compared to the weekly snapshots. In winter, when $\mathrm{pCO}_{2}$ variability is minimal, $\mathrm{TCO}_{2}$ dynamic range is greatest. Winter $\mathrm{TCO}_{2}$ maxima are only $\sim 2050 \mu \mathrm{mol} / \mathrm{kg}$, and the lowest annual values, $\sim 1400 \mu \mathrm{mol} / \mathrm{kg}$ are seen then. These low $\mathrm{TCO}_{2}$ events correspond with freshening events that dilute ocean-source water $\mathrm{TCO}_{2}$, while having little effect on $\mathrm{pCO}_{2}$. During summer, the $\mathrm{TCO}_{2}$ values are overall higher $(\sim 2000-2250 \mu \mathrm{mol} / \mathrm{kg})$. and show less dynamic range than winter.

\section{Single Year Derived Observations}

The full 2017-year observations the derived terms alkalinity, $\Omega_{a}$, and $\mathrm{pH}_{t}$, are shown in Figures 4G-I. Alkalinity shows similar wintertime variability to $\mathrm{TCO}_{2}$, with lower maximum concentrations (compared to summer) and strong salinity- and $\mathrm{TCO}_{2}$-covariance leading to a dynamic range of $\sim 1400$ $2200 \mu \mathrm{mol} / \mathrm{kg}$. During summer, alkalinity reaches its highest values near $2300 \mu \mathrm{mol} / \mathrm{kg}$, while variability is low with minimum values rarely falling below $2200 \mu \mathrm{mol} / \mathrm{kg}$. Wintertime $\Omega_{a}$ generally falls in the range of $1-2$, except for some values $\sim 0.5$ corresponding to the lowest observed salinities. Summertime dynamics show extreme ranges from $\sim 0.7$ to 5 , coinciding with the similarly maximal dynamic range in $\mathrm{pCO}_{2}$ and $\mathrm{pH}_{t}$. Winter $\mathrm{pH}_{t}$ shows little variability, mostly captured with the range 7.9-8.1. Springtime $\mathrm{pH}_{t}$ values are amplified relative to winter, ranging from 7.6 to 8.5 , meanwhile summer $\mathrm{pH}_{t}$ shows strong variability between 7.5 and 8.4. The spring transition out of the dominant wintertime regime 


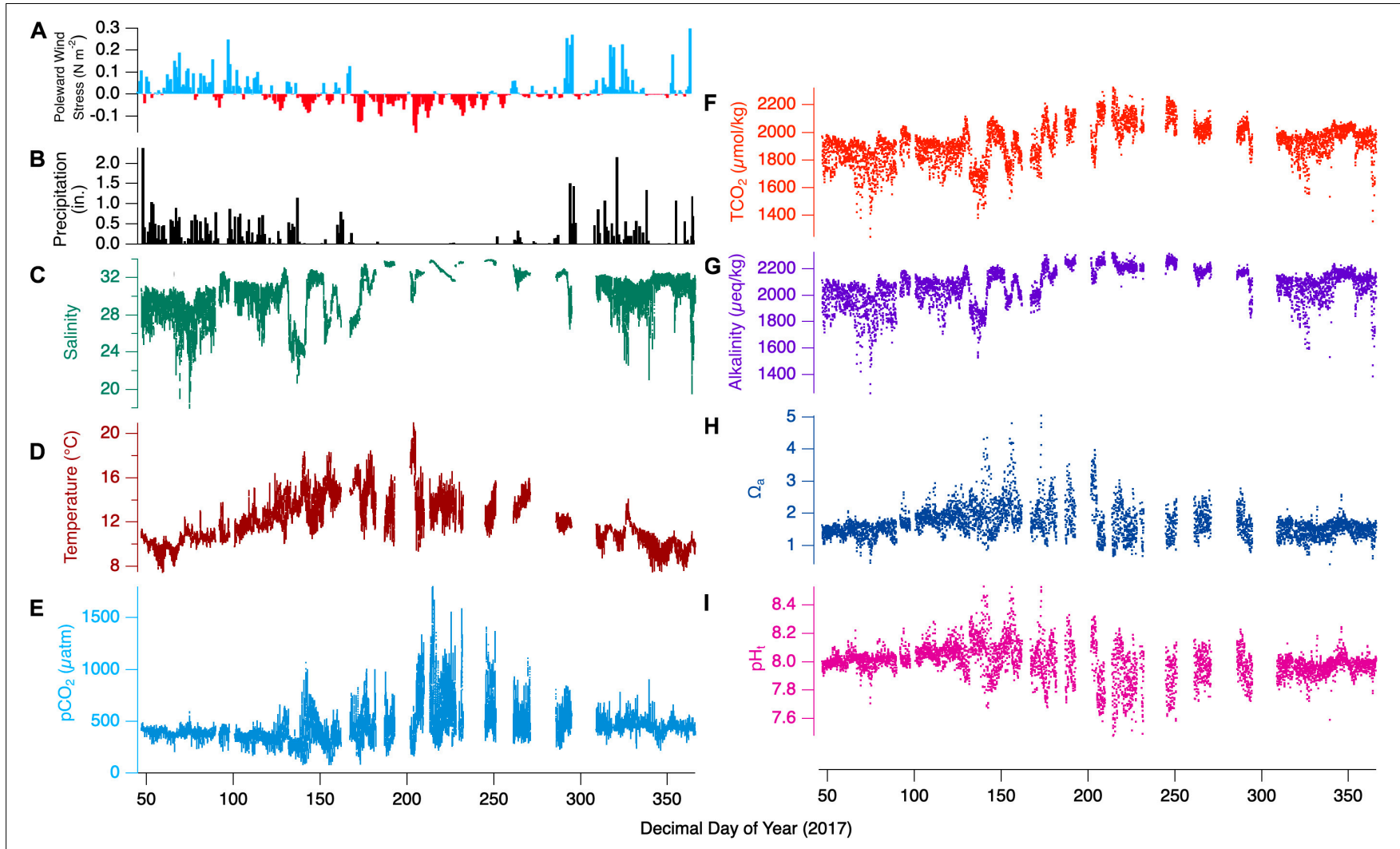

FIGURE 4 | Full 2017-year observations for Netarts Bay, OR. (A) Poleward wind stress, (B) daily precipitation in inches, (C) salinity (teal line), (D) temperature (red line), (E) $\mathrm{pCO}_{2}$ (cyan line), (F) $\mathrm{TCO}_{2}$ (orange dots), (G) calculated alkalinity (purple dots), (H) aragonite saturation state $\left(\Omega_{a}\right.$, blue dots), and (I) pH (pink dots), for the full 2017 timeseries. Wind stress data courtesy of http://damp.coas.oregonstate.edu/windstress/; Precipitation data courtesy of https://www.ncdc.noaa.gov/ cdo-web/.

shows elevated values of $\mathrm{pH}_{t}$ and $\Omega_{a}$, with maxima of 8.5 and 5.0 , respectively. Similarly, alkalinity and $\mathrm{TCO}_{2}$ values become elevated in tandem with intermittent equatorward wind and spring-transition upwelling related events. The reverse occurs during the fall transition as poleward winds become dominant and downwelling prevails.

\section{Composite Year Direct Observations}

Compositing all years' wind stress, precipitation, salinity, temperature, $\mathrm{TCO}_{2}$, and $\mathrm{pCO}_{2}$ data provides the full range of variability in the basic carbonate measurements taken at Netarts Bay from 2014 to 2019 (Figures 5A-F). Over all 6 years, temperature ranges from $\sim 5-20^{\circ} \mathrm{C}$, salinity from $\sim 15$ to 34 , $\mathrm{pCO}_{2}$ from $\sim 100$ to $2500 \mu \mathrm{atm}$, and $\mathrm{TCO}_{2}$ from $\sim 1400$ to $2250 \mu \mathrm{mol} / \mathrm{kg}$. The 2017-year discussed previously falls within the 6-year composite, and the general patterns hold: winter is dominated by poleward winds and high precipitation, while summer is dominated by equatorward winds and nearly absent precipitation. Wintertime $\mathrm{pCO}_{2}$ and temperature exhibit lower variability while summer values show dynamic ranges that nearly encompass the full data-set dynamic range. Wintertime salinity and $\mathrm{TCO}_{2}$ show lower maxima than seen in summer, and the lowest minima seen all year, while values are higher and less variant in summer.

\section{Composite-Year Derived Observations}

Figures 5G-I adds all years' calculated alkalinity, $\mathrm{pH}_{t}$, and $\Omega_{a}$ observations to the previously discussed $\mathrm{pCO}_{2}$ and $\mathrm{TCO}_{2}$. Alkalinity ranges from $\sim 1150$ to $2400 \mu \mathrm{eq} / \mathrm{kg}, \Omega_{a}$ from $\sim 0.3$ to 5.0, and $\mathrm{pH}_{t}$ from $\sim 7.5$ to 8.6. As above, the general patterns seen for the 2017-year persist: alkalinity is overall lower in winter but experiences the largest variability with extreme minima that correspond to the lowest salinity events, while summer alkalinity experiences its highest values and lower variability. $\Omega_{a}$ shows low variability mostly captured in the range 1-2 in winter, with instances of very low $\Omega_{a}$ associated with the lowest-salinity events, while summer conditions show large variability, ranging from 0.7 to 5.0. $\mathrm{pH}_{t}$ variability is low in winter months and exceeds $1 \mathrm{pH}$ unit in summer, coincident with the large observed range in $\mathrm{pCO}_{2}$.

\section{DISCUSSION}

\section{Timescales and Drivers of Variability}

Netarts Bay experiences dynamic variability across multiple hydrographic and carbonate parameters at timescales from diel to tidal to several days to seasonal. This variability occurs in response to a variety of factors, namely in-bay metabolic 


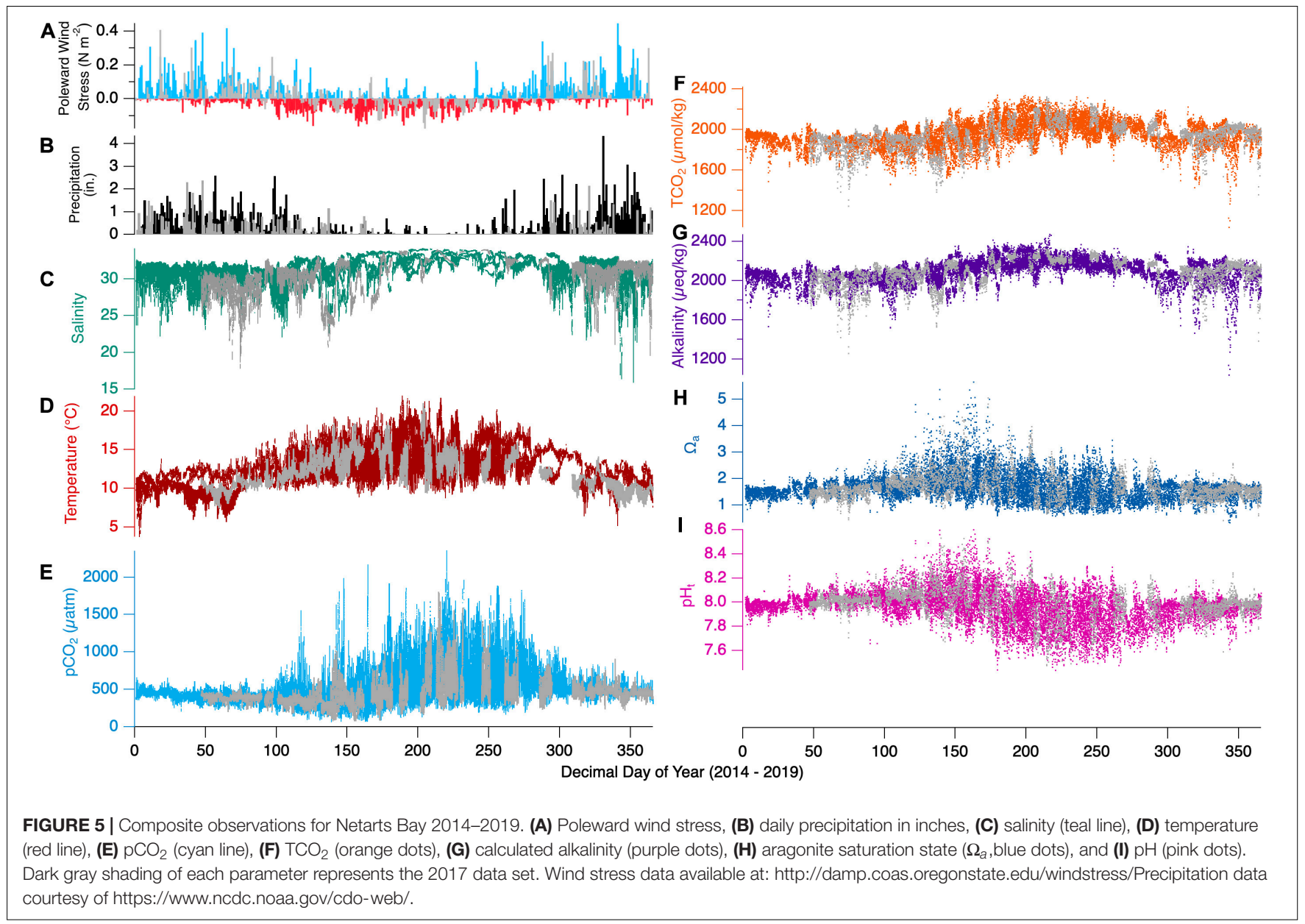

processes, advection of various water masses into the bay, adjacent coastal wind forcing, and daytime insolation. In this section we examine and hypothesize certain factors driving the observed variability at multiple timescales.

\section{Diel Synchrony and Tide Phasing}

The previously described diel variability of in-bay $\mathrm{pCO}_{2}$ is characterized by a gradual decline throughout the afternoon until a diel minimum is reached in late afternoon or early evening, followed by a gradual build up overnight until an early morning maximum is reached. This pattern is evident in both summer and winter, though with lower amplitude in winter (Figure 2). Coincident with the diel variability, however, is a strong tidal forcing that cannot be clearly separated from the diel forcing in the 1-week snapshots presented earlier. With relatively short water residence times $(\sim 12 \mathrm{~h})$, tidal forcing is evident in salinity, and to some degree $\mathrm{TCO}_{2}$ and alkalinity variability, particularly in winter. The semi-diurnal tides are not perfectly in phase with the diel variability, however, but shift forward nearly $40 \mathrm{~min}$ each day. Therefore, if tidal forcing were the dominant control, we would see the $\mathrm{pCO}_{2}$ variability reverse phase with respect to the day on $\sim$ fortnightly intervals. Figures $6 \mathbf{A}, \mathbf{B}$ shows $\mathrm{pCO}_{2}$ and $\mathrm{TCO}_{2}$ variability across two 5-day periods in summer 2017 with tide phasing shifted roughly 90 degrees between the top and bottom graph. In each representation, $\mathrm{pCO}_{2}$ trends down during daylight hours to reach a lateday minimum and increases overnight to an early morning maximum. Similarly, wintertime conditions show diel $\mathrm{pCO}_{2}$ behavior which trend down in response to daytime insolation and rise slightly overnight (Figures 6C,D) even when comparing periods of orthogonal tide heights.

The apparent driver of this diel variability is the net metabolism driven by a composite of processes in the bay. The balance between primary production, which consumes $\mathrm{CO}_{2}$ in the presence of sunlight and nutrients to create organic matter, and respiration, which releases $\mathrm{CO}_{2}$ during the degradation of organic matter, drives diel $\mathrm{pCO}_{2}$ variability. During summer, when the photoperiod is extended due to higher incident solar angle and prolonged daylight, insolation is at its maxima; coincidentally, upwelling supplies the bay and coastal ocean with elevated nutrients (Oregon coast upwelledwater $\mathrm{NO}_{3}{ }^{-}>35 \mu \mathrm{M}$; Hales et al., 2005). The abundant epibenthic primary producers and the high surface-area:volume ratio of the bay-floor relative to the water column leads to extensive modification of the overlying water, despite rapid tidal flushing. Broadly, the reverse occurs once the lights turn off and heterotrophic metabolism tips the scales, producing an abundance of $\mathrm{TCO}_{2}$. This addition of dissolved carbon dioxide 

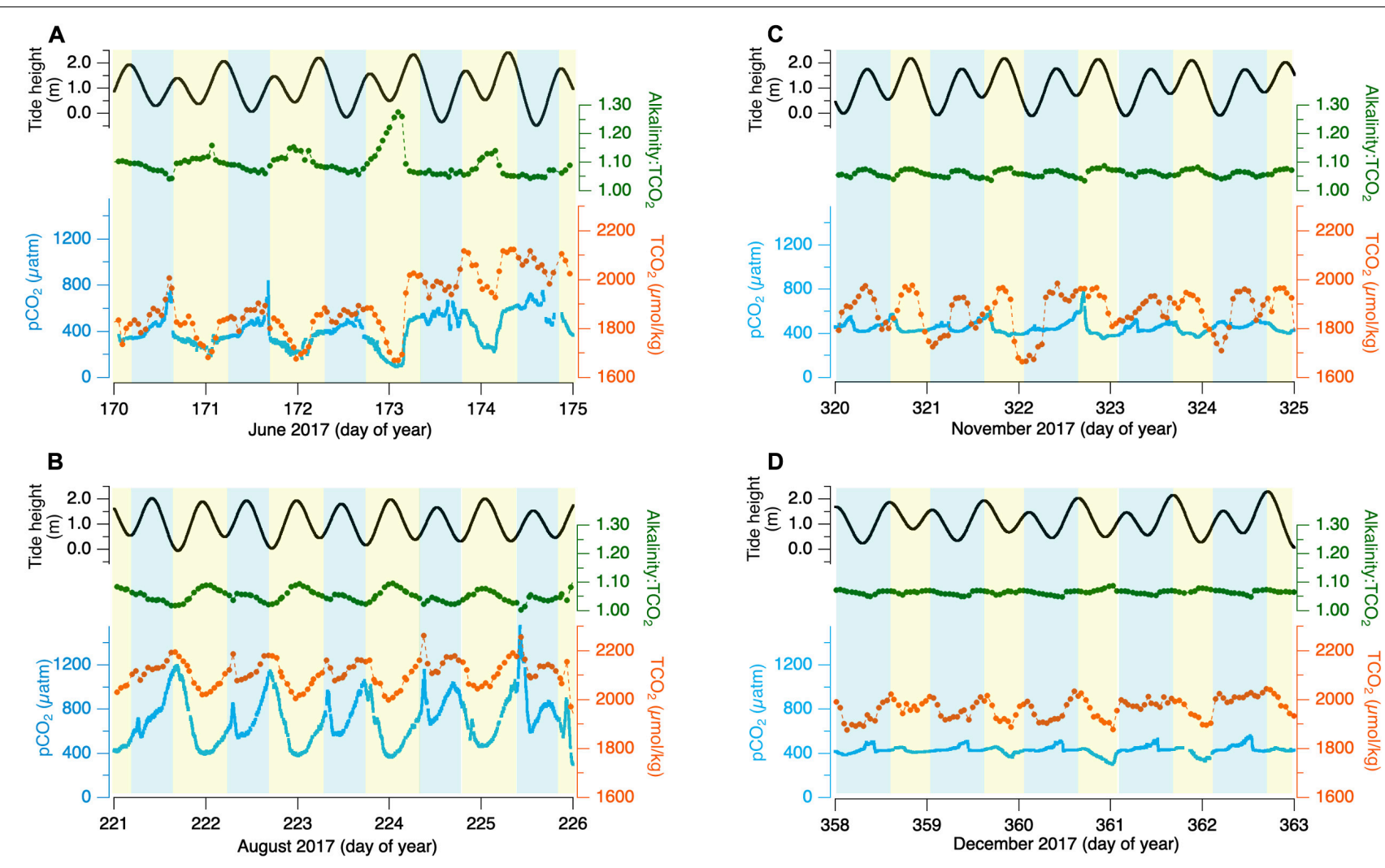

FIGURE 6 | $\mathrm{pCO}_{2}$ (blue line), $\mathrm{TCO}_{2}$ (orange dots connected by a line), Alk: $\mathrm{TCO}_{2}$ ratio (red starts connected by a line), and estimated tide height (black line) for two 7-day periods during summer (A,B) and winter (C,D) of 2017 with tide-phasing $\sim 90^{\circ}$ between top and bottom. Blue shading indicates local nighttime and yellow shading indicates daytime.

shifts the carbonate chemistry such that $\mathrm{pCO}_{2}$ at times passes $2000 \mu \mathrm{atm}$ as seen in the early morning spring months of 2019 (data not shown) in response to strong and sustained equatorward winds and subsequent offshore upwelling.

This mechanism is supported further by the close coherence of $\mathrm{pCO}_{2}$ and $\mathrm{TCO}_{2}$ during the productive summer season, while alkalinity variability remains small. Aerobic net community metabolism impacts primarily $\mathrm{TCO}_{2}$, with much smaller impact on alkalinity, and thus carries an implied $\mathrm{pCO}_{2}$ and $\mathrm{TCO}_{2}$ covariance. For $\mathrm{T} \sim 12^{\circ} \mathrm{C}, \mathrm{S} \sim 33$, the relative change in $\mathrm{pCO}_{2}$ is 12 times the relative change of $\mathrm{TCO}_{2}$ [Revelle Factor of 12 (Revelle and Suess, 1957; Broecker et al., 1979; Sundquist et al., 1979)], for all other variables constant. Relative variability in $\mathrm{pCO}_{2}$ daily minimum and maximum for the intervals depicted ranges 10-20 times that for $\mathrm{TCO}_{2}$, adding support to the idea that net metabolism, modulated by diel insolation cycles, is the primary driver of summertime bay carbonate-system variability.

Nested within the day-night variability is an apparent tidal signature, most evident in the "dual-peaks" signature in the $\mathrm{pCO}_{2}$ behavior in Figure 6B. This tidal signal is complicated, however, by the variable synchronicity between ocean upwelling and relaxation, the tide state, and insolation. For example, during strong upwelling, high- $\mathrm{pCO}_{2}$ freshly upwelled water will be present adjacent to the bay-mouth. If this water flows into the bay in the evening following a sunny day when in-bay productivity has reduced the $\mathrm{pCO}_{2}$ of bay waters, the rising tide will coincide with rising bay $\mathrm{pCO}_{2}$. Conversely, if relaxation has allowed productive ocean waters with depleted $\mathrm{pCO}_{2}$ to be pushed against the shore and these waters enter the bay early in the morning after in-bay respiration has increased bay-water $\mathrm{pCO}_{2}$, the rising tide will correspond with falling bay $\mathrm{pCO}_{2}$. The persistent diel insolation-coupled periodicity in summertime, despite the range of ocean conditions and tide/insolation phasing emphasizes the dominance of in-bay metabolism.

The wintertime conditions are somewhat more challenging to explain, as the diel variability in $\mathrm{pCO}_{2}$ is muted but persists in the face of clearly tidally modulated alkalinity and $\mathrm{TCO}_{2}$. Even within broad ranges of $\mathrm{TCO}_{2}$ and alkalinity, $\mathrm{pCO}_{2}$ is largely driven by changes in the ratio of $\mathrm{TCO}_{2}$ :alkalinity (Figures $6 \mathrm{C}, \mathrm{D}$ ). Although there are important variations in the salinity-alkalinity relationships, discussed below, the leading factor is freshwater dilution of ocean water, which largely preserves the oceanic $\mathrm{TCO}_{2}$ :alkalinity ratio. The large tidally driven salinity-covariant $\mathrm{TCO}_{2}$ variability is thus compensated by covarying alkalinity. The responding factors like $\mathrm{pCO}_{2}$ and $\mathrm{pH}_{t}$ show distinct patterns of variability, with the diel character persisting. The metabolic signature is expected to be suppressed relative to summer. Lower insolation angle, shorter photoperiod, and increased cloudiness limit the potential maximum photosynthetic rate, and wintertime coastal waters carry significantly lower nutrient concentrations 
than upwelled source waters (Wetz et al., 2006). This reduced metabolic signature is consistent with observed reductions in inbay biomass during winter, when the extensive seagrass beds seen in summer have vanished.

\section{Event-Scale Variability}

Imposed onto the observed carbonate dynamics are eventscale processes which act on timescales of days to weeks. The predominantly summertime equatorward winds which drive offshore Ekman transport and upwelling occur in cycles of strong wind-forcing/relaxation periods. The duration, timing of onset, and intensity of these cycles are governed by synoptic-scale highpressure systems and occur on variable time and space scales along the West Coast (Pringle and Dever, 2009; Aristizábal et al., 2017). One such transition from wind relaxation to upwelling is captured in the 2017 summer interval (Figures 2, 3), which show a clear hydrographic and carbonate-variable influence of high-salinity, - $\mathrm{TCO}_{2}$ and -alkalinity deep-upwelled-source water entering the bay coincident with a strengthening of equatorward wind. The wind-relaxation event which occurred prior, days 169-173, was concurrent with salinity, $\mathrm{TCO}_{2}$ and alkalinity below $32,2000 \mu \mathrm{mol} / \mathrm{kg}$, and $2100 \mu \mathrm{eq} / \mathrm{kg}$, respectively. The windstress time-series for the full year 2017 (Figure 4) shows days to weeks of prevailing equatorward winds followed by instances of brief relaxation periods and/or light poleward winds. These relaxation cycles coincide with warmer water temperatures, lower and more tidally synchronized salinity and alkalinity, and a slight dampening of diel $\mathrm{pCO}_{2}$ dynamics in response to reduced input of dissolved nutrients as the bay's primary water source shifts from deep upwelled water to open Pacific Ocean surface water.

Event-scale variability occurs throughout the downwellingwintertime regime as well as when the influence of predominantly California current water $(S \sim 32.5)$ is interrupted by brief but intense storm-dominated conditions. During the winter of 2017, multiple low-pressure fronts moved over the Oregon coast (Figure 4), depositing several inches of rain over brief $(\sim 48$ h, days 361-363) windows. The combination of direct dilution and mixing of local coastal freshwater endmembers represented by discharge from small mountainous rivers resulted in large negative salinity, alkalinity, and $\mathrm{TCO}_{2}$ departures from the overall background downwelling conditions. Rapid tidal flushing and a return to precipitation-free downwelling in the days following storm conditions quickly returned the bay to normal wintertime variability.

\section{Seasonal Upwelling and Downwelling}

At seasonal timescales, we observe large differences in character and variability of nearly all hydrographic and carbonate parameters between the summer and winter. The clear driver of these stark summer-winter differences is the regional transition from upwelling-dominated high-insolation summer conditions with equatorward winds and low precipitation, to downwelling-dominated low-insolation winter conditions with frequent intense precipitation events. These background seasonal differences set the stage for the distinct behavior and variability timescales seen in the different seasons.
Interceding these two states are transition seasons where the character of the dominant season fades and the impending season emerges. In the fall transition, upwelling favorable winds wane in the September-October timeframe, while the winter storms build in October-November. In the spring transition, intervals between winter storm events have building upwelling character. The bay's seasons are thus driven largely by the initiation and termination of coastal upwelling and downwelling. There have been detailed studies regarding the variability of the onset of upwelling in this region (Pierce et al., 2006); similarly wintertime precipitation events are highly variable interannually.

\section{Behavior of Alkalinity}

For much of the open surface ocean, alkalinity is affected primarily by local removal (by evaporation and/or ice formation) and addition (by precipitation and/or ice-melt) of near zeroalkalinity fresh water (Brewer et al., 1986; Lee et al., 2006). Mixing of water masses results in single, conservative (linear) alkalinitysalinity relationships that can be applied within large oceanic subregions (Takahashi et al., 2014). We have compared regionally published alkalinity-salinity relationships for North Pacific subregion (Takahashi et al., 2014, Eq. 2; Cullison Gray et al., 2011, Eq. 3, adapted from the published form for consistency) to that acquired from the comprehensive 2014-2019 WCSH measurements (Figure 7; Eq. 4):

$$
\begin{gathered}
\text { Alkalinity }=44.88 *(\text { Salinity })+724.6 \\
\text { Alkalinity }=50.8 *(\text { Salinity }-31.25)+2131 \\
\text { Alkalinity }=50.8 *(\text { Salinity })+543 \\
\text { Alkalinity }=53.1 *(\text { Salinity })+440
\end{gathered}
$$

While the WCSH results are broadly consistent with the other regional regressions, particularly at salinities approaching open Pacific Ocean surface waters $(S>32$, average salinity-based alkalinity predictions deviated \pm 15 upmueq $/ \mathrm{kg}$ when compared to observed), there are multiple and discrete trends which depart from both the regional relationships and the comprehensive WCSH alkalinity/salinity relationship. These differences appear to be real and mechanistic. Although the Takahashi et al. (2014) relationship is based on a nitrate-corrected 'potential alkalinity' and the Cullison Gray et al. (2011) results are not, the difference between their mostly open-ocean products is likely to be only a few $\mu \mathrm{eq} / \mathrm{kg}$. Our results are also uncorrected for nitrate, and while the corrections for our data are likely to be higher, they are still expected to be less than $\sim 35 \mu \mathrm{eq} / \mathrm{kg}$ (given the $\mathrm{NO}_{3}{ }^{-}$levels in upwelled source water; Hales et al., 2005) and without clear salinity dependence. While all three relationships are broadly consistent with each other at the highest salinities, there is a clear tendency toward higher salinity dependence (slope) and lower apparent freshwater endmember (intercept) in the WCSH data, as well as deviation of the direct alkalinity determinations 


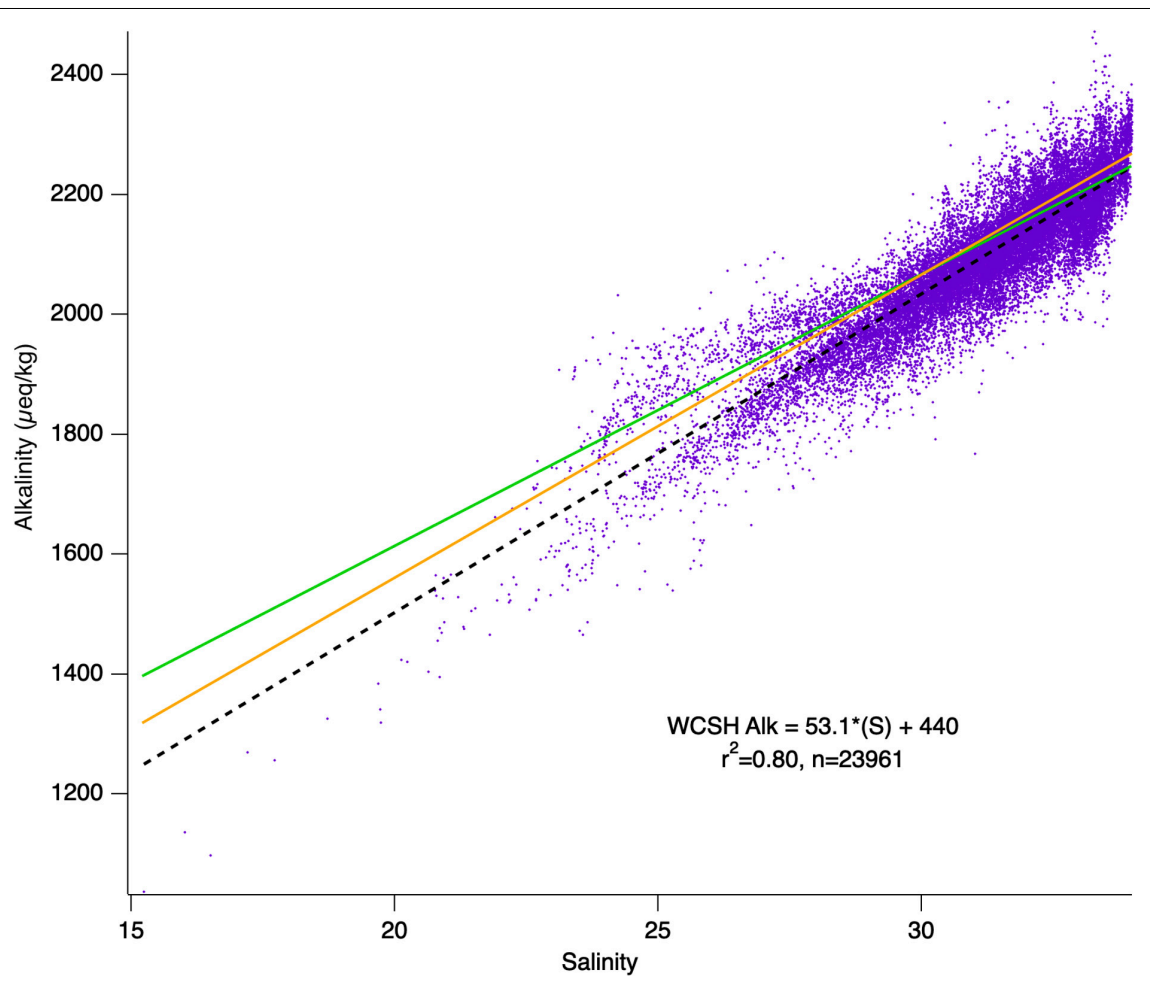

FIGURE 7 | Composite alkalinity-salinity regression for all years 2014-2019 and associated correlation statistics. Purple dots represent hourly calculated alkalinity data and black dashed line represents a simple linear-fit. Published regional alkalinity-salinity relationships from from Cullison Gray et al. (2011; orange), and Takahashi et al. (2014; green) are overlain.

from the regression of the full WCSH dataset that exceed the analytical uncertainty.

The existence of regional predictive relationships for alkalinity from the relatively more-easily measured salinity, as well as the large-scale coherence between salinity and alkalinity seen in our data, offers potential for assessing ocean acidification-relevant parameters using measurement of a single parameter, such as $\mathrm{pCO}_{2}$, and a salinity-based estimate of alkalinity. Our direct determinations of alkalinity, however, show several systematic departures from all three 'regional' predictions that exceed our analytical uncertainty. These cause significant error in calculation of un-measured parameters, and can be broadly divided into two categories: conservative mixing with multiple end-members; and non-conservative behavior driven by in-bay metabolic-processes.

\section{Identifying Multiple End-Members}

From late fall to early spring, metabolic activity in the bay is suppressed and salinity variability is comparatively high relative to summer conditions. During these intervals, there is strong linear covariance between alkalinity and salinity over a variety of timescales with $R^{2}$ values frequently exceeding 0.9. During these months, WCSH alkalinity is well-predicted by the full-dataset, Cullison Gray et al. (2011), and Takahashi et al. (2014) relationships when the salinity is relatively high and the variability is moderate (Figure $\mathbf{8 A}$, days 72-74; Figure $\mathbf{8 B}$, days 128-131). This likely reflects mixing of California Current surface waters with mixed winter-time Oregon shelf waters (Wetz et al., 2006; Whitney and Garvine, 2006; Banas et al., 2009; Pfeiffer-Herbert et al., 2016). More extreme freshening, however, causes systematic deviation from the regional predictions, in both the positive and negative sense. Figure 8A, day 74 shows a strong alkalinity decrease coinciding with freshening driven by a 24 -h period of intense local rainfall and watershed runoff. In this case, the directly determined alkalinity is 200$280 \mu \mathrm{eq} / \mathrm{kg}$ lower than the regional predictions, reflecting the very-low alkalinity of precipitation and event-driven runoff from Netarts Bay's small watershed. Regression of alkalinity vs. salinity in these events (inset) suggests a freshwater endmember of $115 \mu \mathrm{eq} / \mathrm{kg}$, low even in comparison to coast range river water ( $300 \mu \mathrm{eq} / \mathrm{kg}$; Pfeiffer-Herbert et al., 2016; Hales, unpublished) and indicative of the importance of direct precipitation on the bay. For this precipitation event, the WCSH-regression alkalinity (Eq. 4) combined with the directly measured $\mathrm{pCO}_{2}$ resulted in overestimates of the actual $\mathrm{TCO}_{2}$ by $164 \pm 28 \mu \mathrm{mol} / \mathrm{kg}, \mathrm{pH}_{t}$ by $0.06 \pm 0.01$, and $\Omega_{a}$ by $0.10 \pm 0.02$. In comparison, the Cullison Gray et al. (2011) alkalinity model would overestimate $\mathrm{TCO}_{2}$ by $192 \pm 33 \mu \mathrm{mol} / \mathrm{kg}, \mathrm{pH}_{t}$ by $0.07 \pm 0.01$ and $\Omega_{a}$ by $0.10 \pm 0.02$. Likewise, the Takahashi et al. (2014) alkalinity model would overestimate $\mathrm{TCO}_{2}, \mathrm{pH}_{t}$, and $\Omega_{a}$ as much as $257 \pm 48 \mu \mathrm{mol} / \mathrm{kg}$, $0.09 \pm 0.02$, and $0.14 \pm 0.03$, respectively.

Other low-salinity deviations show the opposite effect. Figure 8B, days 132-135 shows low-alkalinity conditions, also driven by strong freshening of bay-water. Rather than falling below the regionally predicted alkalinity, observations exceed 
— Cullison Gray et al., (2011) — Takahashi et al., (2014) — WCSH composite regression - - WCSH direct measurement
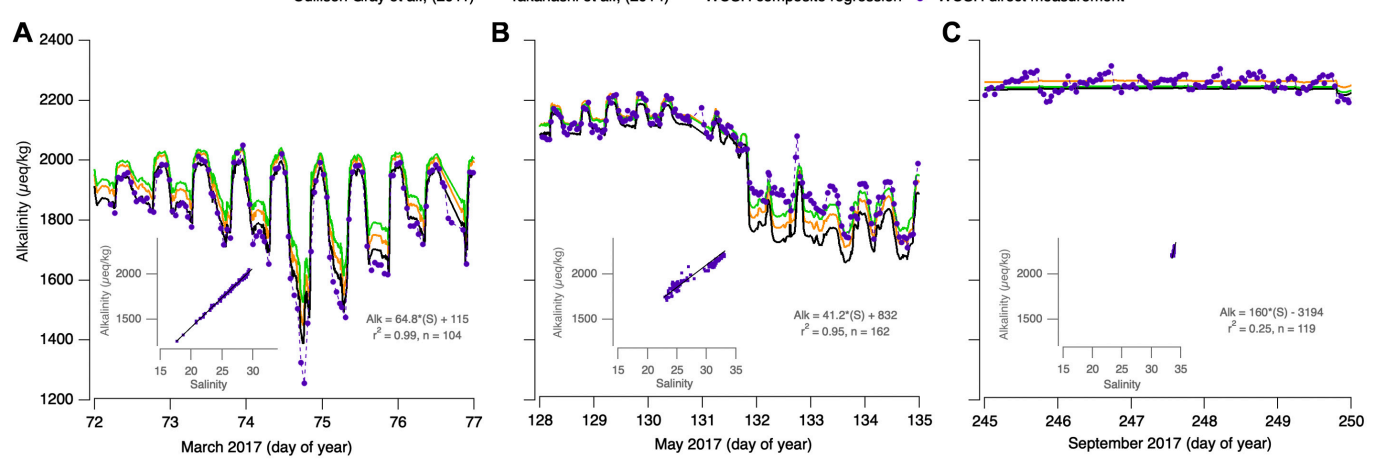

FIGURE 8 | Reconstruction and comparison of directly determined WCSH alkalinity (purple dots connected by a dashed line) and WCSH-composite regression determined alkalinity (black line) against two published regional alkalinity-salinity relationships from Cullison Gray et al. (2011) (orange), and Takahashi et al. (2014) (green). Three intervals are depicted: downwelling interceded by a precipitation event on day 74 (A), apparent Columbia River plume intrusion days 132-135 (B), and persistently high salinity during an upwelling interval (C). Associated alkalinity-salinity regression insets for (A-C) are displayed in gray.

the regional salinity-based predictions, by $64-134 \mu \mathrm{eq} / \mathrm{kg}$. In this case, oscillating upwelling/downwelling forcing as the spring transition is approached is thought to introduce Columbia River plume waters into the bay. Under downwelling forcing, coastal flow is poleward and onshore, typically trapping the plume along the Washington coastline. Under the opposite flow of upwelling forcing, the plume is pushed equatorward, $100 \mathrm{~km}$ or more south of the river mouth, but typically sits offshore near the shelf break (Banas et al., 2009). Periods of upwelling, followed by reversals to downwelling are thought to push the southwarddisplaced plume onshore (Mazzini et al., 2015), thus bringing Columbia-induced freshening to the bay mouth. In this case, regressions (Figure 8B, inset) indicate a freshwater endmember of $832 \mu \mathrm{eq} / \mathrm{kg}$, higher than any of the regional relationships and consistent with the composition of Columbia River water (USGS National Stream Quality Accounting Network ${ }^{2}$; Evans et al., 2013). These deviations are significant not just in alkalinity, but in the parameters that might be calculated from a predicted alkalinity and WCSH-measured $\mathrm{pCO}_{2}$. For Cullison Gray et al. (2011) $\mathrm{TCO}_{2}$ estimates would be underpredicted by as much as $188 \pm 37 \mu \mathrm{mol} / \mathrm{kg} ; \mathrm{pH}$ by $0.04 \pm 0.01$ and $\Omega_{a}$ by $0.52 \pm 0.08$. Similarly, Takahashi et al. (2014) at times would underpredict $\mathrm{TCO}_{2}$ by $182 \pm 34 \mu \mathrm{mol} / \mathrm{kg} ; \mathrm{pH}$ by $0.05 \pm 0.01$ and $\Omega_{a}$ by $0.44 \pm 0.08$. WCSH-regression alkalinity resulted in the largest observed underestimations in $\mathrm{TCO}_{2}, \mathrm{pH}_{t}$, and $\Omega_{a}$ of $224 \pm 41 \mu \mathrm{mol} / \mathrm{kg}, 0.06 \pm 0.01$, and $0.56 \pm 0.12$, respectively.

\section{Metabolic-Process Dominance}

The strong alkalinity-salinity coupling observed during downwelling-favorable conditions tends to break down during persistent upwelling intervals. During these summertime conditions, precipitation and local-river discharge is effectively absent, the Columbia River plume is far offshore, and the in-bay salinity variability is minimal. In spite of this, alkalinity variability is high and significantly in excess of our analytical uncertainty. Even when regressions were statistically significant with high

${ }^{2}$ https://nrtwq.usgs.gov/nwqn/\#/ linearity, the coefficients were geochemically unrealistic: slopes with magnitudes many times any reported values and with both positive and negative sign. Similarly, observed alkalinity was as much as $58 \mu \mathrm{eq} / \mathrm{kg}$ different from the regional relationships (Figure 8C), in both positive and negative senses. These results suggested that any alkalinity-salinity covariance was fortuitous, and that the alkalinity variability was driven by processes other than mixing or dilution/concentration. Regression of these data (Figure 8C, inset) generates low predictive power $\left(R^{2}=0.25\right)$ and geochemically unrealistic slope and intercept values. Parameters calculated from WCSH-regression alkalinity and those provided by Cullison Gray et al. (2011) and Takahashi et al. (2014) were all similarly in error: $\mathrm{TCO}_{2}$ overestimated at times by $108 \pm 21 \mu \mathrm{mol} / \mathrm{kg}, \mathrm{pH}_{t}$ by $0.02 \pm 0.01, \Omega_{a}$ by $0.14 \pm 0.02$.

Non-physical processes that can change bay alkalinity include the consumption/release of protons in proportion to nitrate uptake/regeneration during oxic photosynthesis/respiration; $\mathrm{CaCO}_{3}$ formation and dissolution; and suboxic respiration such as sulfate reduction and pyrite formation (Brewer and Goldman, 1976; Hu and Cai, 2011; Cai et al., 2017). While any of these processes are probably occurring, net calcification seems most likely to have the greatest effect. Aerobic nitrate cycling should result in anti-correlated alkalinity: $\mathrm{TCO}_{2}$ with a $\sim 1: 7$ ratio (Dickson, 1981; Wolf-Gladrow et al., 2007), and this is not evident. Further, net autotrophy within the bay, as suggested by the seasonal buildup of seagrass beds, would seemingly result in a growing alkalinity over the course of the summer season, which is also not observed. In contrast, summer alkalinity frequently departs negatively from expected salinity dependences. The only process that can drive these negative departures in the face of strong biological $\mathrm{pCO}_{2}$ depletion is net precipitation of $\mathrm{CaCO}_{3}$. It is hard to quantify the net $\mathrm{CaCO}_{3}$ precipitation independently, but the bay is a location of abundant and resilient shellfish communities.

\section{Implications for Ocean Acidification}

Whiskey Creek Shellfish Hatchery experienced the immediate impacts of ocean acidification during the 2008 growing season 
when intake water containing naturally elevated $\mathrm{CO}_{2}$-further enhanced by anthropogenic $\mathrm{CO}_{2}$ - killed off millions of larval shellfish, placing the hatchery in danger of permanent shutdown (Barton et al., 2012, 2015). Along the adjacent coastal shelf, water influenced by anthropogenic carbon has been documented upwelling onto the shelf (Feely et al., 2008), creating potentially corrosive conditions for marine calcifiers and threatening to fundamentally alter the marine food-web. Instances of ocean acidification-related shellfish mortality and various other implications of changing carbonate chemistry are expected to continue worsening through the end of century (IPCC, 2014), and the work of coastal monitoring and public communication and engagement will be essential toward developing potential mitigation strategies.

In the coastal environment with dramatically variable carbonate chemistry within relatively small spatial scales, monitoring ocean acidification requires a broad network of buoys, field scientists, and volunteers (Hofmann et al., 2011; Takeshita et al., 2015). These operations are often times many millions of dollars (Strong et al., 2014) and the commercial fisheries and shellfish industries rely on accurate, reliable assessment of coastal water quality as it relates to specific organisms. Frequently, $\mathrm{pH}$ probes are used to measure $\mathrm{pH}$ because they are relatively easy tools to use. However, $\mathrm{pH}$ measurements come with inherent measurement uncertainties and often are unreliable predictors of more relevant ocean acidification parameters for marine calcifiers such as $\Omega_{a}$ (Gimenez et al., 2019), specifically in salinity-variable settings such as estuaries. Similarly, coastal mooring sites reveal that low $\mathrm{pH}$ and low $\Omega_{a}$ do not necessarily overlap (Sutton et al., 2016). A 3-year study of Willapa Bay carbonate chemistry revealed that for a nominal $\mathrm{pH}_{t}$ value of $7.7, \Omega_{a}$ ranged from $<0.5$ to 1.5 (Hales et al., 2017) suggesting that reliance on $\mathrm{pH}$ probes alone, without consideration of other carbonate variables, may over- or underestimate optimal seawater growing conditions for hatchery owners. For a nominal $\mathrm{pH}$ of 7.7 across all years at WCSH, $\Omega_{a}$ ranged from 0.9 to 1.8 .

Understanding and predicting organismal response to ocean acidification represents a primary challenge in determining the fate of marine calcifiers in the face of an increasingly corrosive marine environment. For example, laboratory studies suggest that Crassostrea gigas (Pacific oyster) larvae begin to experience acute physiological stress in seawater with $\Omega_{a}<1$.7; below 1.4 significant developmental stunting and potential larval shellfish mortality can occur (Barton et al., 2012; Waldbusser et al., 2015b); while $\Omega_{a}<1.0$ and the system thermodynamically favors dissolution of mineral calcium carbonate back into solution. In the context of $\mathrm{WCSH}$, which primarily raise C. gigas larvae, monitoring and adjusting intake water $\Omega_{a}$ (Waldbusser et al., 2015a) have led to increased hatchery success (Barton et al., 2015), and far fewer instances of mass larval mortality.

Utilizing hourly calculated $\Omega_{a}$ at WCSH for all years of this study, $\Omega_{a}$ measured less than 1.7 during $58 \%$ of instances, $<1.4$ for $31 \%$ of instances, and $<1.06 \%$ of the time, with the most frequent events $<1.4$ occur during the late-summer months (Figure 5H). While the ecological thresholds for optimal and suboptimal shellfish spawning are well known for C. gigas, the exact timing of natural larval shellfish spawning remains an ongoing research question. For WCSH, few native oyster populations are found within the bay owing in part to lack of suitable substrate, while mussels are found inhabiting the rocky tidal shores near the mouth of the bay. Clams represent the dominant native shellfish population of Netarts Bay. The success of any native shellfish population which may inhabit the bay is critically dependent on overlapping spawning times with optimal carbonate conditions-particularly within the first 48$\mathrm{h}$ when shellfish are at the highest risk of mortality in corrosive conditions (Waldbusser et al., 2015a).

\section{The Impact of Anthropogenic $\mathbf{C O}_{2}$}

The Pacific ocean inventory of $\mathrm{CO}_{2}$ is increasing at a rate of approximately $0.41 \pm 0.13 \mathrm{~mol} \mathrm{C} / \mathrm{m}^{2} / \mathrm{yr}(0.82 \pm 0.26 \mathrm{Pg}$ $\mathrm{C} / \mathrm{yr}$ ) (Quay et al., 2017) primarily by means of ocean surface gas exchange with the atmosphere. Estimates place the total increase in concentration of $\mathrm{TCO}_{2}$ in upper surface ocean layers along the west coast of North America on the order of 37$63 \mu \mathrm{mol} / \mathrm{kg}$, although these values vary spatially (Khatiwala et al., 2013; Feely et al., 2016). Using a conservative nominal value of $37 \mu \mathrm{mol} / \mathrm{kg}\left(\Delta \mathrm{TCO}_{2, \text { anth }}\right)$ added to this region of the ocean since 1850 , we estimated what conditions would have been like for WCSH without any added anthropogenic carbon by subtracting $37 \mu \mathrm{mol} / \mathrm{kg}$ from the $\mathrm{TCO}_{2}$ observations and recalculating $\mathrm{pH}_{t}$ and $\Omega_{a}$.

On average, the addition of $37 \mu \mathrm{mol} / \mathrm{kg} \mathrm{TCO}_{2}$ to the oceans has resulted in average WCSH $\mathrm{pH}_{t}$ and $\Omega_{a}$ values approximately 0.1 and 0.30 units lower, respectively, when compared to pre-industrial estimates. This is in line with global evaluations that surface ocean $\mathrm{pH}_{t}$ has declined 0.1 units since the start of the Industrial Revolution (Feely et al., 2004) and that surface ocean saturation state is in a current state of global decline (Friedrich et al., 2012; Jiang et al., 2015). Applying a conservative fixed anthropogenic $\mathrm{TCO}_{2}$ addition of $37 \mu \mathrm{mol} / \mathrm{kg}$ for all years 2014-2019 (Figure 9), we find the relative impact of anthropogenic carbon on $\mathrm{pH}_{t}$ and $\Omega_{a}$ is variable throughout upwelling and downwelling events, with no statistically significant interannual variation from 2014 to 2019. Astoundingly, when $\Omega_{a}$ conditions are elevated during the late-spring/early-summer months (Figure $\mathbf{5 H}$ ), the apparent contribution of anthropogenic carbon to reduced $\Omega_{a}$ is at its greatest (Figure 9, top). Moreover, the contribution of $\Delta \mathrm{TCO}_{2, \text { anth }}$ to $\mathrm{pH}_{t}$ appears to be at its annual minimum during this period, suggesting a decoupling mechanism between $\mathrm{pH}_{t}$ and $\Omega_{a}$. While our evaluation likely underestimates the true value of $\Delta \mathrm{TCO}_{2}$, anth for Oregon coast source water and assumes $\Delta \mathrm{TCO}_{2}$, anth remains fixed between 2014 and 2019, we find the results useful in demonstrating the way in which Netarts Bay is effected by ocean acidification. Implementing a fixed $\Delta \mathrm{TCO}_{2}$, anth reveals both a decline in the mean $\mathrm{pH}_{t}$ and saturation state, as well as more frequent low- $\mathrm{pH}_{t}$, low-saturation state events (Figure 10). Using this estimate, the frequency of low saturation state events $\left(\Omega_{a}<1.5\right)$ has increased nearly $240 \%$ while that of undersaturation $\left(\Omega_{a}<1.0\right)$ events has increased sevenfold. Continued oceanic uptake of carbon will continue to push $\mathrm{pH}_{t}$ and $\Omega_{a}$ below their modern values, with high-latitude surface 

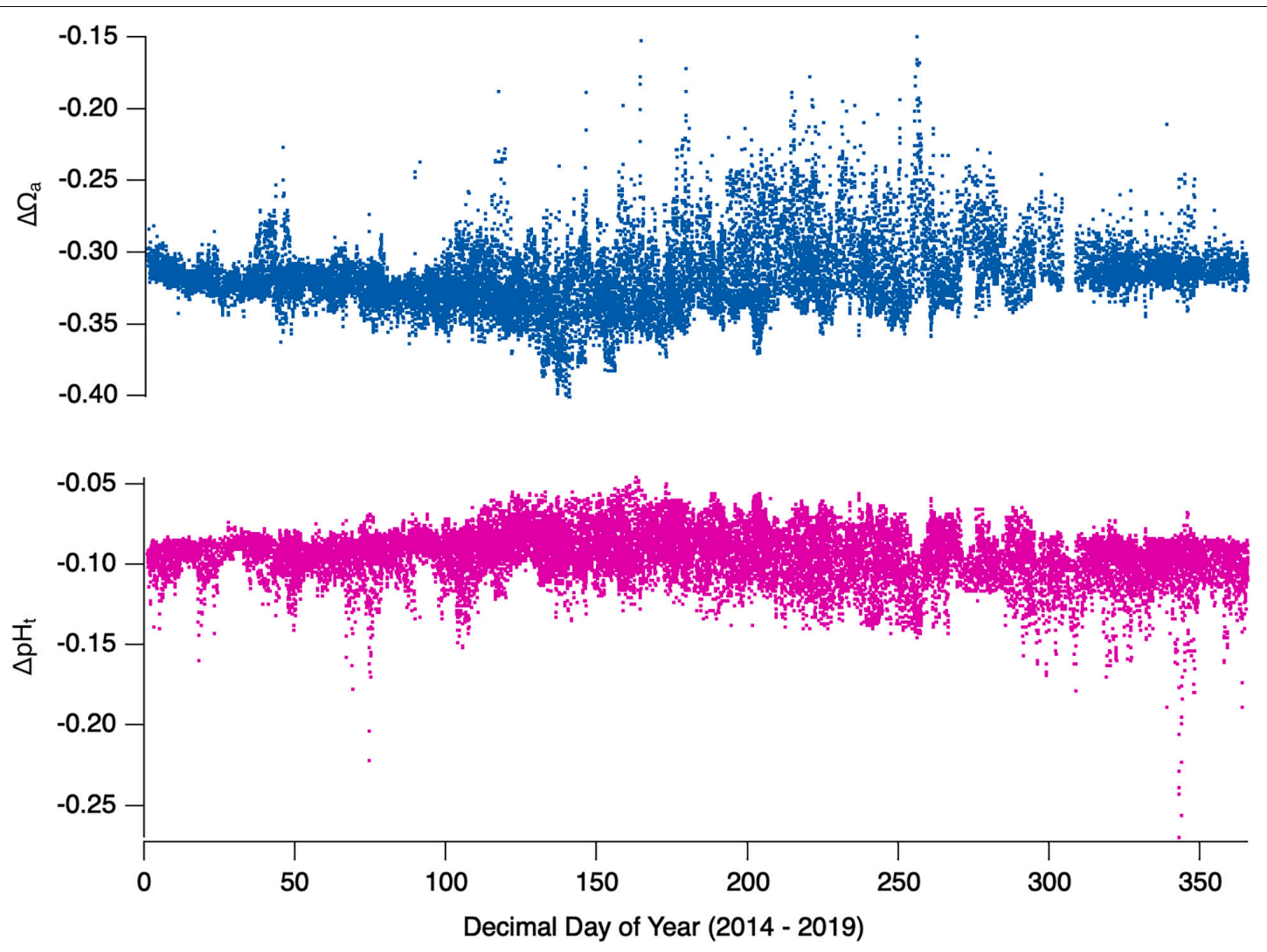

FIGURE $9 \mid \Delta \Omega_{a}$ (top) and $\Delta \mathrm{pH}_{t}$ (bottom) calculated for all years 2014-2019 at WCSH using a conservative nominal value of $37 \mu \mathrm{mol} / \mathrm{kg} \mathrm{TCO}_{2}$ added to west coast of United States surface water since 1850. Values represent approximate negative departures due to anthropogenic $\mathrm{CO}_{2}$.
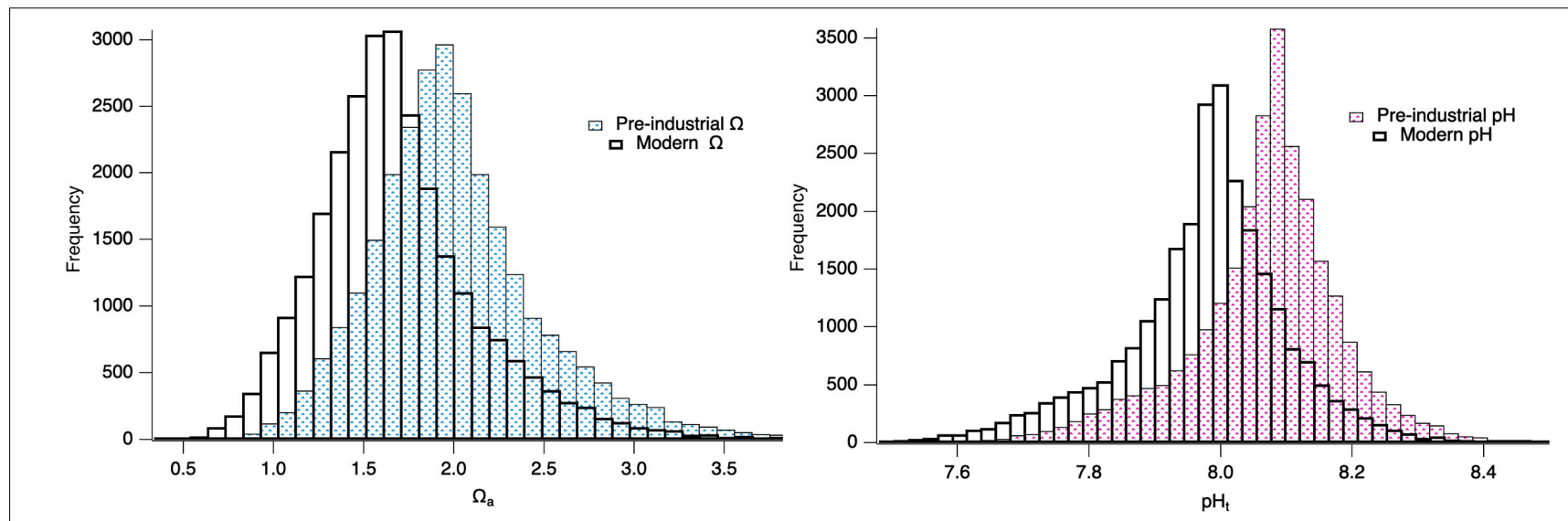

FIGURE 10 | Histogram plot of all hourly calculated $\Omega_{a}$ (Left) and $\mathrm{pH}_{t}$ (Right) for the 2014-2019 WCSH timeseries.

waters expected to be fully undersaturated by the end of century (Feely et al., 2009).

\section{CONCLUSION}

Netarts Bay is a metabolically dynamic, ocean-dominated estuarine environment with hydrographic and carbonate-system variability occurring on multiple timescales. Summer upwelling, wintertime downwelling, and in situ bay biogeochemistry represent significant drivers of the observed variability in carbonate dynamics. Data presented here show the seasonality, intensity, and duration of high- $\mathrm{pCO}_{2}$ events while illuminating diel, seasonal, and annual patterns of carbonate-system dynamics. Direct estimates of total alkalinity from paired $\mathrm{pCO}_{2}$ and $\mathrm{TCO}_{2}$ measurements suggest local biogeochemical 
processes not captured by regional, open-ocean alkalinity-salinity relationships. Additionally, in line with global estimates of global surface ocean $\mathrm{pH}_{t}$ and calcium carbonate saturation decline, we find that WCSH has experienced an approximate decline in $\mathrm{pH}_{t}$ and $\Omega_{a}$ of $\sim 0.1$ and $\sim 0.30$ units, respectively, since 1850 .

\section{DATA AVAILABILITY STATEMENT}

The raw data supporting the conclusions of this article will be made available by the authors, without undue reservation.

\section{AUTHOR CONTRIBUTIONS}

$\mathrm{BH}$ was responsible for instrument development. $\mathrm{BH}$ and $\mathrm{WF}$ were responsible for data acquisition, analysis, and interpretation.

\section{REFERENCES}

Aristizábal, M. F., Fewings, M. R., and Washburn, L. (2017). Effects of the relaxation of upwelling-favorable winds on the diurnal and semidiurnal water temperature fluctuations in the Santa Barbara channel, California. J. Geophys. Res. Oceans 122, 7958-7977. doi: 10.1002/2017JC0 13199

Banas, N. S., MacCready, P., and Hickey, B. M. (2009). The Columbia River plume as cross-shelf exporter and along-coast barrier. Cont. Shelf Res. 29, 292-301. doi: 10.1016/j.csr.2008.03.011

Bandstra, L., Hales, B., and Takahashi, T. (2006). High-frequency measurements of total CO2: method development and first oceanographic observations. Mar. Chem. 100, 24-38. doi: 10.1016/j.marchem.2005.10.009

Barton, A., Hales, B., Waldbusser, G. G., Langdon, C., and Feely, R. A. (2012). The Pacific oyster, Crassostrea gigas, shows negative correlation to naturally elevated carbon dioxide levels: implications for near-term ocean acidification effects. Limnol. Oceanography 57, 698-710. doi: 10.4319/lo.2012.57.3. 0698

Barton, A., Waldbusser, G., Feely, R., Weisberg, S., Newton, J., Hales, B., et al. (2015). Impacts of coastal acidification on the Pacific Northwest shellfish industry and adaptation strategies implemented in response. Oceanography 25, 146-159. doi: 10.5670/oceanog.2015.38

Brewer, P. G., Bradshaw, A. L., and Williams, R. T. (1986). "Measurements of total carbon dioxide and alkalinity in the North Atlantic Ocean in 1981," in The Changing Carbon Cycle: A Global Analysis, eds J. R. Trabalka and D. E. Reichle (New York, NY: Springer), 348-370. doi: 10.1007/978-1-4757-1915-4_18

Brewer, P. G., and Goldman, J. C. (1976). Alkalinity changes generated by phytoplankton growth1: alkalinity changes. Limnol. Oceanography 21, 108-117. doi: 10.4319/lo.1976.21.1.0108

Broecker, W. S., Takahashi, T., Simpson, H. J., and Peng, T.-H. (1979). Fate of fossil fuel carbon dioxide and the global carbon budget. Science 206, 409-418. doi: $10.1126 /$ science.206.4417.409

Cai, W.-J., Huang, W.-J., Luther, G. W., Pierrot, D., Li, M., Testa, J., et al. (2017). Redox reactions and weak buffering capacity lead to acidification in the Chesapeake Bay. Nat. Commun. 8:369. doi: 10.1038/s41467-017-00417-7

Cullison Gray, S. E., DeGrandpre, M. D., Moore, T. S., Martz, T. R., Friederich, G. E., and Johnson, K. S. (2011). Applications of in situ pH measurements for inorganic carbon calculations. Mar. Chem. 125, 82-90. doi: 10.1016/j.marchem. 2011.02.005

Diaz, R. J., and Rosenberg, R. (2008). Spreading dead zones and consequences for marine ecosystems. Science 321, 926-929. doi: 10.1126/science.1156401

Dickson, A. G. (1981). An exact definition of total alkalinity and a procedure for the estimation of alkalinity and total inorganic carbon from titration data. Deep Sea Res. Part A. Oceanographic Res. Papers 28, 609-623. doi: 10.1016/0198-0149(81) 90121-7

\section{FUNDING}

Funding from NOAA OAP and IOOS programs through an Ocean Technology Transfer award (NA14NOS0120151) and sustained support to NANOOS (NA16NOS0120019).

\section{ACKNOWLEDGMENTS}

The data are available: https://ir.library.oregonstate.edu/concern/ datasets/9z903634r?locale=en. We would like to thank the continued participation of the WCSH team, including the sterling leadership of Sue Cudd and Alan Barton, faculty participation and assistance in routine maintenance of the laboratory including Marnie Jo Zirbel, Dale Hubbard, and Joe Jennings, as well as undergraduate and graduate student assistance from Carrie Weekes, Selina Lambert, and Michael Moses.

Dickson, A. G. (1990). Thermodynamics of the dissociation of boric acid in synthetic seawater from 273.15 to 318.15 K. Deep Sea Res. Part A. Oceanographic Res. Papers 37, 755-766. doi: 10.1016/0198-0149(90)90004-F

Evans, W., Hales, B., and Strutton, P. G. (2013). pCO2 distributions and air-water CO2 fluxes in the Columbia River estuary. Estuarine, Coastal Shelf Sci. 117, 260-272. doi: 10.1016/j.ecss.2012.12.003

Evans, W., Pocock, K., Hare, A., Weekes, C., Hales, B., Jackson, J., et al. (2019). Marine CO2 patterns in the Northern Salish Sea. Front. Mar. Sci. 5:536. doi: 10.3389/fmars.2018.00536

Evans, W., Hales, B., and Strutton, P. G. (2011). Seasonal cycle of surface ocean pCO2 on the oregon shelf. J. Geophys. Res. Atmospheres 116, C05012. doi: 10.1029/2010JC006625

Fassbender, A. J., Alin, S. R., Feely, R. A., Sutton, A. J., Newton, J. A., Krembs, C., et al. (2018). Seasonal carbonate chemistry variability in marine surface waters of the US Pacific Northwest. Earth System Sci. Data 10, 1367-1401. doi: 10.5194/essd-10-1367-2018

Feely, R. A., Alin, S. R., Carter, B., Bednaršek, N., Hales, B., Chan, F., et al. (2016). Chemical and biological impacts of ocean acidification along the west coast of North America. Estuarine, Coastal Shelf Sci. 183, 260-270. doi: 10.1016/j.ecss. 2016.08.043

Feely, R. A., Doney, S. C., and Cooley, S. R. (2009). Ocean acidification : present conditions and future changes in a high-CO2 world. Oceanography 22, 36-47. doi: 10.5670/oceanog.2009.95

Feely, R. A., Sabine, C. L., Hernandez-Ayon, J. M., Ianson, D., and Hales, B. (2008). Evidence for upwelling of corrosive "Acidified" water onto the continental shelf. Science 320, 1490-1492. doi: 10.1126/science.1155676

Feely, R. A., Sabine, C. L., Lee, K., Berelson, W., Kleypas, J., Fabry, V. J., et al. (2004). Impact of anthropogenic $\mathrm{CO} 2$ on the $\mathrm{CaCO} 3$ system in the oceans. Science 305, 362-366. doi: 10.1126/science.1097329

Friedrich, T., Timmermann, A., Abe-Ouchi, A., Bates, N. R., Chikamoto, M. O., Church, M. J., et al. (2012). Detecting regional anthropogenic trends in ocean acidification against natural variability. Nat. Climate Change 2, 167-171. doi: $10.1038 /$ nclimate 1372

Gimenez, I., Waldbusser, G. G., Langdon, C. J., and Hales, B. R. (2019). The dynamic ocean acidification manipulation experimental system: separating carbonate variables and simulating natural variability in laboratory flowthrough experiments. Limnol. Oceanography: Methods 17, 343-361. doi: 10. 1002/lom 3.10318

Glanzman (1971). Tidal Hydraulics, Flushing Characteristics and Water Quality of Netarts Bay. Corvallis: Oregon State University.

Hales, B., Chipman, D., and Takahashi, T. (2004). High-frequency measurement of partial pressure and total concentration of carbon dioxide in seawater using microporous hydrophobic membrane contactors. Limnol. Oceanography: Methods 2, 356-364. doi: 10.4319/lom.2004. 2.356 
Hales, B., Moum, J. N., Covert, P., and Perlin, A. (2005). Irreversible nitrate fluxes due to turbulent mixing in a coastal upwelling system. J. Geophys. Res.: Oceans 110, doi: 10.1029/2004JC002685

Hales, B., Suhrbier, A., Waldbusser, G. G., Feely, R. A., and Newton, J. A. (2017). The carbonate chemistry of the "Fattening line," Willapa Bay, 2011-2014. Estuar. Coasts; Port Republic 40, 173-186. doi: 10.1007/s12237-016-0136-7

Hofmann, G. E., Smith, J. E., Johnson, K. S., Send, U., Levin, L. A., Micheli, F., et al. (2011). High-Frequency dynamics of ocean pH: a Multi-Ecosystem comparison. PLoS One 6:e28983. doi: 10.1371/journal.pone.0028983

Hu, X., and Cai, W.-J. (2011). An assessment of ocean margin anaerobic processes on oceanic alkalinity budget: anaerobic alkalinity production. Global Biogeochem. Cycles 25:GB3003. doi: 10.1029/2010GB003859

Ianson, D., Allen, S. E., Harris, S. L., Orians, K. J., Varela, D. E., and Wong, C. S. (2003). The inorganic carbon system in the coastal upwelling region west of Vancouver Island, Canada. Deep Sea Res. Part I: Oceanographic Res. Papers 50, 1023-1042. doi: 10.1016/S0967-0637(03)00114-6

Jiang, L.-Q., Feely, R. A., Carter, B. R., Greeley, D. J., Gledhill, D. K., and Arzayus, K. M. (2015). Climatological distribution of aragonite saturation state in the global oceans. Global Biogeochem. Cycles 29, 1656-1673. doi: 10.1002/ 2015GB005198

Kennish, M. J. (2002). Environmental threats and environmental future of estuaries. Environmental Conserv. 29, 78-107. doi: 10.1017/ S0376892902000061

Khatiwala, S., Tanhua, T., Mikaloff Fletcher, S., Gerber, M., Doney, S. C., Graven, H. D., et al. (2013). Global ocean storage of anthropogenic carbon. Biogeosciences 10, 2169-2191. doi: 10.5194/bg-10-2169-2013

Lee, K., Tong, L. T., Millero, F. J., Sabine, C. L., Dickson, A. G., Goyet, C., et al. (2006). Global relationships of total alkalinity with salinity and temperature in surface waters of the world's oceans. Geophys. Res. Lett. 33:L19605. doi: 10.1029/2006GL027207

Mazzini, P. L. F., Risien, C. M., Barth, J. A., Pierce, S. D., Erofeev, A., Dever, E. P., et al. (2015). Anomalous near-surface low-salinity pulses off the central Oregon Coast. Sci. Rep. 5:17145. doi: 10.1038/srep17145

McCallum, L. (1977). Netarts Bay, Oregon: An Assessment of Human Impact on an Estuarine System. Ph.D. thesis, Department of Geography, Portland State University, Portland. doi: 10.15760/etd.2548

Millero, F. J. (2010). Carbonate constants for estuarine waters. Mar. Freshwater Res. 61, 139-142. doi: 10.1071/MF09254

Mucci, A. (1983). The solubility of calcite and aragonite in seawater at various salinities, temperatures, and one atmosphere total pressure. Am. J. Sci. 283, 780-799. doi: 10.2475/ajs.283.7.780

Nemcek, N., Ianson, D., and Tortell, P. D. (2008). A high-resolution survey of DMS, CO2, and O2/Ar distributions in productive coastal waters. Global Biogeochem. Cycles 22:GB2009. doi: 10.1029/2006GB002879

Peirson, W., Davey, E., Jones, A., Hadwen, W., Bishop, K., Beger, M., et al. (2015). Opportunistic management of estuaries under climate change: a new adaptive decision-making framework and its practical application. J. Environ. Manag. 163, 214-223. doi: 10.1016/j.jenvman.2015.08.021

Pfeiffer-Herbert, A. S., Prahl, F. G., Hales, B., Lerczak, J. A., Pierce, S. D., and Levine, M. D. (2016). High resolution sampling of methane transport in the Columbia River near-field plume: implications for sources and sinks in a river-dominated estuary. Limnol. Ocean. 61, S204-S220. doi: 10.1002/lno.10221

Pierce, S. D., Barth, J. A., Thomas, R. E., and Fleischer, G. W. (2006). Anomalously warm July 2005 in the northern California current: historical context and the significance of cumulative wind stress. Geophys. Res. Lett. 33. doi: 10.1029/ 2006GL027149

Pringle, J. M., and Dever, E. P. (2009). Dynamics of wind-driven upwelling and relaxation between Monterey Bay and point arena: local-, regional-, and gyre-scale controls. J. Geophys. Res.: Oceans 114. doi: 10.1029/2008JC005016

Quay, P., Sonnerup, R., Munro, D., and Sweeney, C. (2017). Anthropogenic CO2 accumulation and uptake rates in the Pacific Ocean based on changes in the $13 \mathrm{C} / 12 \mathrm{C}$ of dissolved inorganic carbon. Global Biogeochem. Cycles 31, 59-80. doi: 10.1002/2016GB005460

Rabalais, N. N., Turner, R. E., Diaz, R. J., and Justic, D. (2009). Global change and eutrophication of coastal waters. ICES J. Mar. Sci. 66, 1528-1537. doi: 10.1093/icesjms/fsp047

Revelle, R., and Suess, H. E. (1957). Carbon dioxide exchange between atmosphere and ocean and the question of an increase of atmospheric $\mathrm{CO} 2$ during the past decades. Tellus 9, 18-27. doi: 10.1111/j.2153-3490.1957.tb01849.x
Strong, A. L., Kroeker, K. J., Teneva, L. T., Mease, L. A., and Kelly, R. P. (2014). Ocean acidification 2.0: managing our changing coastal ocean chemistry. BioScience 64, 581-592. doi: 10.1093/biosci/biu072

Sundquist, E. T., Plummer, L. N., and Wigley, T. M. L. (1979). Carbon dioxide in the ocean surface: the homogeneous buffer factor. Science 204, 1203-1205. doi: $10.1126 /$ science.204.4398.1203

Sutton, A. J., Sabine, C. L., Feely, R. A., Cai, W.-J., Cronin, M. F., McPhaden, M. J., et al. (2016). Using present-day observations to detect when anthropogenic change forces surface ocean carbonate chemistry outside preindustrial bounds. Biogeosciences 13, 5065-5083. doi: 10.5194/bg-13-50652016

Takahashi, T., Sutherland, S. C., Chipman, D. W., Goddard, J. G., Ho, C., Newberger, T., et al. (2014). Climatological distributions of pH, pCO2, total $\mathrm{CO} 2$, alkalinity, and $\mathrm{CaCO} 3$ saturation in the global surface ocean, and temporal changes at selected locations. Mar. Chem. 164, 95-125. doi: 10.1016/j. marchem.2014.06.004

Takeshita, Y., Frieder, C. A., Martz, T. R., Ballard, J. R., Feely, R. A., Kram, S., et al. (2015). Including high-frequency variability in coastal ocean acidification projections. Biogeosciences 12, 5853-5870. doi: 10.5194/bg-12-58532015

van Geen, A., Takesue, R. K., Goddard, J., Takahashi, T., Barth, J. A., and Smith, R. L. (2000). Carbon and nutrient dynamics during coastal upwelling off Cape Blanco, Oregon. Deep Sea Res. Part II: Top. Stud. Oceanography 47, 975-1002. doi: 10.1016/S0967-0645(99)00133-2

Vance, J. M. (2012). Proof-of-Concept: Automated High-Frequency Measurements of pCO2 and TCO2 and Real-time Monitoring of the Saturation State of Calcium Carbonate. Thesis, Oregon State University: Corvallis, OR.

Waldbusser, G. G., Hales, B., Langdon, C. J., Haley, B. A., Schrader, P., Brunner, E. L., et al. (2015a). Ocean acidification has multiple modes of action on bivalve larvae. PLoS One 10:e0128376. doi: 10.1371/journal.pone.012 8376

Waldbusser, G. G., Hales, B., Langdon, C. J., Haley, B. A., Schrader, P., Brunner, E. L., et al. (2015b). Saturation-state sensitivity of marine bivalve larvae to ocean acidification. Nat. Climate Change 5, 273-280. doi: 10.1038/nclimate 2479

Waldbusser, G. G., and Salisbury, J. E. (2014). Ocean acidification in the coastal zone from an organism's perspective: multiple system parameters, frequency domains, and habitats. Ann. Rev. Mar. Science 6, 221-247. doi: 10.1146/ annurev-marine-121211-172238

Waldbusser, G. G., Voigt, E. P., Bergschneider, H., Green, M. A., and Newell, R. I. E. (2011). Biocalcification in the Eastern oyster (Crassostrea virginica) in relation to long-term trends in chesapeake bay pH. Estuaries Coasts 34, 221-231. doi: 10.1007/s12237-010-9307-0

Wetz, M. S., Hales, B., Chase, Z., Wheeler, P. A., and Whitney, M. M. (2006). Riverine input of macronutrients, iron, and organic matter to the Coastal Ocean off Oregon, U.S.A., during the Winter. Limnol. Oceanography 51, 2221-2231. doi: 10.4319/lo.2006.51.5.2221

White, M. M., McCorkle, D. C., Mullineaux, L. S., and Cohen, A. L. (2013). Early exposure of bay scallops (Argopecten irradians) to high $\mathrm{CO}_{2}$ causes a decrease in larval shell growth. PLoS One 8:e61065. doi: 10.1371/journal.pone.0061065

Whitney, M. M., and Garvine, R. W. (2006). Simulating the delaware bay buoyant outflow: comparison with observations. J. Phys. Oceanography 36, 3-21. doi: 10.1175/JPO2805.1

Wolf-Gladrow, D. A., Zeebe, R. E., Klaas, C., Körtzinger, A., and Dickson, A. G. (2007). Total alkalinity: the explicit conservative expression and its application to biogeochemical processes. Mar. Chem. 106, 287-300. doi: 10. 1016/j.marchem.2007.01.006

Conflict of Interest: The authors declare that the research was conducted in the absence of any commercial or financial relationships that could be construed as a potential conflict of interest.

Copyright (C) 2021 Fairchild and Hales. This is an open-access article distributed under the terms of the Creative Commons Attribution License (CC BY). The use, distribution or reproduction in other forums is permitted, provided the original author(s) and the copyright owner(s) are credited and that the original publication in this journal is cited, in accordance with accepted academic practice. No use, distribution or reproduction is permitted which does not comply with these terms. 